\title{
The Democratic Deficit in the States
}

\author{
Jeffrey R. Lax Columbia University \\ Justin H. Phillips Columbia University
}

\begin{abstract}
We study how well states translate public opinion into policy. Using national surveys and advances in subnational opinion estimation, we estimate state-level support for 39 policies across eight issue areas, including abortion, law enforcement, health care, and education. We show that policy is highly responsive to policy-specific opinion, even controlling for other influences. But we also uncover a striking "democratic deficit": policy is congruent with majority will only half the time. The analysis considers the influence of institutions, salience, partisan control of government, and interest groups on the magnitude and ideological direction of this democratic deficit. We find the largest influences to be legislative professionalization, term limits, and issue salience. Partisanship and interest groups affect the ideological balance of incongruence more than the aggregate degree thereof. Finally, policy is overresponsive to ideology and party-leading policy to be polarized relative to state electorates.
\end{abstract}

$\mathrm{H}$ ow responsive is state policy to public opinion? Erikson, Wright, and McIver (1993) overturned the long-standing view that the public had little influence and established a clear correlation between voter ideology and aggregate state policy. Simply put, liberal states have more liberal policy. Subsequent studies of policymaking at the state level have reached similar conclusions. By this test, then, statehouse democracy receives a passing grade.

One might worry, however, that this test is too lenient. The ideology-policy correlation is the dominant approach in studies of state responsiveness, and it has been the most fruitful approach to date. However, problems of inference arise because researchers cannot know exactly how diffuse preference measures ought to translate into policy. That is, policy and ideology lack a common metric (Erikson, Wright, and McIver 1993, 93; Matsusaka 2001). For example, how liberal should policy be in a state in which $30 \%$ of voters self-identify as liberal? Clearly, policy in a state with $35 \%$ liberals should be even more liberal, but how much more? A high correlation between ideology and policy reveals a strong relationship between the two, but without knowing the mapping of ideology to voter policy preferences, we cannot tell if policy is over- or underresponsive to preferences.

Most existing work, by focusing on the ideologypolicy correlation, also does not assess how responsive states are to voter preferences on specific policies. Nor does it tell us how effective state political systems are at translating opinion majorities into public policy. If a majority of voters in a state wants to adopt a lottery or impose an abortion restriction, how likely is the state to do so? In other words, is policy usually congruent with majority will?

Both responsiveness and congruence are forms of policy representation, but they capture different dimensions of democratic performance. To be clear, by responsiveness, we mean a positive correlation between opinion and policy; by congruence, we mean that policy actually matches majority opinion. Where majority will is truly sovereign, you would expect both strong responsiveness and a high level of congruence. Policy adoption may increase with higher public support (suggesting responsiveness), but policy may still often be inconsistent with majority opinion (suggesting a lack of congruence),

Jeffrey R. Lax is Associate Professor, Department of Political Science, Columbia University, 420 W. 118th, MC3320, New York, NY 10027 (JRL2124@columbia.edu). Justin H. Phillips is Associate Professor, Department of Political Science, Columbia University, 420 W. 118 th, MC3320, New York, NY 10027 (JHP2121@columbia.edu).

For helpful comments and discussion, we thank Fred Boehmke, Tom Clark, Robert Erikson, Andrew Gelman, Shigeo Hirano, Andrew Karch, Tom Ogorzalek, Robert Shapiro, Elizabeth Theiss Smith, Christopher Wlezien, and Gerald Wright. We also thank seminar/panel participants at the 2009 State Politics and Policy Conference, Temple University, University of California - Berkeley, Emory University, the 2010 Midwest Political Science Association Annual Meeting, the 2009 American Political Science Association Annual Meeting, and at the Russell Sage Foundation. For research assistance, we thank Jared Drucker, Jacob Feldman, and Thomas Langer. Earlier drafts of this article received the State Politics and Policy Quarterly Award for Best Paper presented at any professional meeting in 2009 and the Pi Sigma Alpha Award for Best Paper at the 2010 Annual Meeting of the Midwest Political Science Association. (Replication data can be obtained from the authors or from their faculty websites.)

American Journal of Political Science, Vol. 56, No. 1, January 2012, Pp. 148-166

(C) 2011, Midwest Political Science Association

DOI: $10.1111 / \mathrm{j} .1540-5907.2011 .00537 . x$ 
perhaps because policymaking is biased in the liberal or conservative direction. In fact, there can be significant responsiveness without congruence.

We argue that a full picture of statehouse democracy requires studying both. The existing literature establishes a high degree of responsiveness to ideology and attitudes (this contribution should not be understated), but not generally to policy-specific opinion, and it cannot usually answer questions about congruence. Doing so raises severe methodological challenges because of the lack of state polling data and the difficulties of estimating voters' preferred policy choices. Our work relies on recent advances in estimating state-level opinion using national data, advances which enable our substantive findings about responsiveness and congruence and allow us to draw out theoretical distinctions between them.

We build on the rich state politics and public opinion literatures to develop a distinct and fine-grained assessment of how well state policymaking conforms to the public will. Our approach reveals a rich set of new "stylized facts" about statehouse democracy and allows us to carefully grade, and explain variation in, democratic performance in the American states. On the positive side, we show that in a broad sweep of state policymaking there is clear influence of policy-specific opinion over and above the influence of diffuse voter ideology, an effect that is strong and robust across model specifications. This is consistent with, while also adding to, the existing literature, and reveals an even more fundamental form of responsiveness. However, we also uncover a rather striking democratic deficit in state policymaking. Roughly half the time, opinion majorities lose-even large supermajorities prevail less than $60 \%$ of the time. In other words, state governments are on average no more effective in translating opinion majorities into public policy than a simple coin flip.

Together, the presence of clear responsiveness to opinion combined with clear evidence of policy incongruence creates a rather complicated picture of statehouse democracy. We might not be shocked by the democratic deficit were policy-specific opinion irrelevant. But it creates a deeper puzzle to find so large a deficit when policyspecific opinion is one of the strongest determinants of policy. The early literature painted too bleak a picture by casting the public as an ignorant and ineffectual actor at best and finding little to no evidence of any influence of public opinion. Newer literature might imply too rosy a picture.

We explore a more nuanced view of statehouse democracy. Specifically, we study the magnitude and variation of the democratic deficit across states, apportioning the "blame" among the forces that shape congruence, and explaining the ideological direction of incongruence.
(Do the "mistakes" tend to be in the liberal or conservative direction?) We consider various determinants of and constraints on democratic performance: which state institutions enhance or distort responsiveness and congruence and whether other forces such as partisanship and interest group activity induce or restrain congruence. We indeed find that the influence of opinion is particularly strong under favorable institutional and political conditions, and for policies of greater salience. We show that there is policy bias associated with incongruence and that it is connected to overresponsiveness to voter ideology and the distorting influence of party control. The net result is that state policy is far more polarized than public preferences.

\section{Studies of Responsiveness}

Early analyses indeed found virtually no relationship between political variables and the ideological direction of state policy (inter alia, Dye 1966; Plotnick and Winters 1985). Treadway (1985), in an influential review of the state policy literature, blamed voters' lack of knowledge and interest in state politics. More recent scholarship, however, dramatically shifted the debate, showing evidence of a linkage between state policy and voter preferences. Erikson, Wright, and McIver estimated voter liberalness in each state by pooling national surveys over a 12-year period and found that the more liberal a state's voters, the more liberal the state scored on a policy index: "even under adverse conditions such as the limited interest and information that the average voter has regarding state politics, public opinion can serve to influence state policy" $(1993,253)$. Subsequent research, employing a similar methodological approach, has confirmed these findings, and other work, such as Stimson, MacKuen, and Erikson (2002), has shown aggregate responsiveness at the national level. To be sure, some policies map quite nicely to general ideology, but some do not (Norrander 2001). Others connect general attitudes (e.g., toward homosexuals or feminism) to related policies and outcomes (e.g., gay marriage bans or number of abortions; Brace et al. 2002; Haider-Markel and Kaufman 2006).

As we noted in the introduction, one concern with using ideology (and even general attitudes) is that we do not know the latent mapping from the diffuse measure to actual policy choice. Some scholars focus on attitudes and ideology because they think it too demanding to expect detailed policy preferences from voters and too demanding to expect statehouse democracy to function on the basis of voters' detailed preferences. But another reason is practical, not theoretical: the lack of comparable opinion polls across states. To compensate for this, studies typically estimate opinion using disaggregation, a 
technique that pools national polls (typically over many years) until there are a sufficient number of survey respondents to calculate opinion percentages in each state. Unfortunately, polling firms do not usually ask policyspecific questions frequently enough to generate reliable estimates of policy-specific preferences. Researchers have instead had to limit themselves to those questions that have been asked in dozens of compatible surveys (the occasional policy question but usually only ideology or attitudes). This limits generalizability across policies and can render conclusions about congruence impossible.

A small number of single-issue studies have directly estimated voters' preferred policy choices and compared those to actual state policies adopted. For example, Gerber $(1996,1999)$ pools several national surveys to estimate state-level support for the death penalty and abortion restrictions; Lax and Phillips (2009b) estimate public support for eight policies regulating gay and lesbian rights; Lupia et al. (2010) uses state polls to study state constitutional bans on same-sex marriage; and Norrander (2000) ties death penalty-specific opinion and policy. While these studies found evidence of responsiveness, results may be difficult to generalize (Burnstein 2003). These studies focus on highly salient morality policy issues, and, as Lax and Phillips (2009b) demonstrate, responsiveness to majority opinion is greatly enhanced by salience.

\section{Responsiveness vs. Congruence}

We address the various concerns above by estimating state-level opinion across a wide range of issues using multilevel regression and poststratification (MRP). MRP is a technique presented by Gelman and Little (1997), validated by Park, Gelman, and Bafumi (2006) and Lax and Phillips (2009a), and extended in Berkman and Plutzer (2005), Lax and Phillips (2009b), and Kastellec, Lax, and Phillips (2010), inter alia. It has been shown to produce highly accurate estimates even with a single national poll and simple demographic-geographic models (simpler than we use herein). There are two stages to MRP. First, individual survey response is modeled as a function of a nuanced demographic and geographic typology, using multilevel regression. For each demographicgeographic type of voter, predicted policy support is estimated. The second step is poststratification: the estimates for each demographic-geographic type are weighted by the percentages of each type in actual state populations using Census data, so that we can estimate the percentage of respondents within each state who take a particular position. This yields estimates of explicit policy support, explicit opposition, and, thereby, policy sup- port among those with an opinion, for each policy, and for each state. For full details of this method, see Lax and Phillips (2009a, 2009b). The demographic predictors used here are age, education, race, and gender. The statelevel variables are percentage religious conservatives and 2004 Democratic presidential vote share, with state and region modeled effects. Below we use percentage support out of those with an opinion.

We use MRP to estimate opinion for 39 policies that are set by state governments. These policies are drawn from eight issue areas: immigration, abortion, criminal justice, health care, gay rights, electoral reform, gaming, and education. These are all issue areas that are salient and over which opinion and policy vary across states. While some, such as abortion, have been the subject of numerous inquiries in the opinion literature, others, such as health care and education, have not. By considering such a diverse set of policies, we can explore whether and how responsiveness and congruence vary across issue areas.

The policies used here are clearly not a random sample, and so some caution must be taken in generalizing our findings. ${ }^{1}$ However, policies were not purposefully selected on substantive grounds or because they lined up with traditional measures of ideology. Rather, the policies included here are all those for which we were able to obtain state policy data and at least one large national opinion survey (though for most policies we rely on multiple surveys). We conducted our search for survey data using iPoll from the Roper Center for Public Opinion Research (see Supporting Information [SI] for details). State policy data were obtained as of 2008 from various sources (SI Table 5), including advocacy groups, policy foundations, and research organizations.

Policy and opinion are both dichotomous, so that they share a directly common metric (e.g., "Does the law require women seeking an abortion to wait 24 hours" and "Do you favor a law requiring women seeking abortions to wait 24 hours?"). Policy and opinion are coded to point in the liberal direction (e.g., having the death penalty is coded as 0 ; having affirmative action is coded as 1 ; codings verified through factor analysis). Policies are listed below (SI Table 5 has details):

- Abortion-Require doctors to counsel patients on abortion alternatives; Require parental consent for teenagers; Require parental notification for teenagers; Ban late-term abortions; Require a 24hour waiting period for an abortion.

- Education-Ban race-based affirmative action for admissions in higher education; Allow charter

\footnotetext{
${ }^{1}$ One exception to our issue coverage is fiscal policy interpreted
} narrowly, though many of the policies do have fiscal implications. 
schools; Require students to pass a standardized test before graduating from high school; Allow taxfunded vouchers to be used for private or religious schools.

- Electoral Reform-Limit corporate/union campaign contributions; Limit individual contributions; Require a photo ID to vote; Allow recall elections; Mandate legislative term limits.

- Gaming-Legalize casino gambling; Legalize a state lottery.

- Gay and Lesbian Rights-Allow second parent adoption statewide; Allow civil unions; Provide health insurance for domestic partners of state employees; Allow same-sex marriage; Legalize samesex sodomy (as of 2003); Include sexual orientation in employment nondiscrimination laws; Include sexual orientation in hate crimes laws; Include sexual orientation in housing nondiscrimination laws.

- Health Care-Legalize physician-assisted suicide; Reduce the number of people who are eligible for Medicaid (in fiscal year 2005); Legalize medical marijuana; Extend eligibility for the State Children's Health Insurance (SCHIP) program to children in a family of four making up to $\$ 60,000$ a year; Allow embryonic stem cell research.

- Immigration-Prohibit public schools from teaching the children of immigrants in their native language (bilingual education); Issue driver's licenses to illegal immigrants; Allow the children of illegal immigrants to attend state public colleges and universities at the same in-state tuition rates as other state residents; Require the state government to verify citizenship status (using the federal government's E-Verify database) before making hiring decisions.

- Law Enforcement-Ban assault weapons; Allow concealed weapons; Allow the death penalty; Mandate prison sentences for nonviolent drug crimes; Decriminalize small amounts of marijuana; Require a waiting period for gun purchases.

Table 1 shows the number of liberal policies and average liberal opinion by state. Table 2 shows the same by issue area. Opinion and policy are mapped in Figure 1.

\section{Responsiveness}

We begin by considering responsiveness at the level of individual policies. Each graph in Figure 2 takes a policy and plots the probability of policy adoption on the $y$ axis, against our estimates of state opinion on the $\mathrm{x}$-axis. The small tick marks along the top (bottom) axis show the opinion in states that have (do not have) the liberal policy.
We show the logit regression curve for each panel. A policy is strongly responsive if it has a steep positively sloped curve. Bold solid curves indicate a statistically significant responsiveness coefficient (at the 95\% level). Otherwise, a dashed curve is plotted. Overall, we find strong evidence of responsiveness, a finding that is strengthened later by multivariate analysis. In all but four graphs, the probability of having liberal policy is positively correlated to policy-specific opinion. However, responsiveness does vary across policies.

First, the strength of the opinion-policy relationship differs, as is indicated by variation in the steepness of the regression curves. Second, policymaking often has either a liberal or conservative bias. To see this, consider the location of the logit curves, which are sometimes shifted left or right of center, meaning either less or more liberal opinion is needed, respectively, to bring about policy adoption. The dotted lines extending from the $\mathrm{x}$ - and $\mathrm{y}$-axes indicate (respectively) where public support and the probability of policy adoption each reach $50 \%$. The point at which the regression curve intersects the vertical dotted line reveals (read on the y-axis) the predicted probability of policy adoption when public support is $50 \%$. The point at which the regression curve intersects the horizontal dotted line reveals (read on the $\mathrm{x}$-axis) the needed level of support for the predicted probability of adoption to reach $50 \%$. The crosshair at the intersection of the two dotted lines marks the point at which 50\% public support corresponds to a $50 \%$ chance of policy adoption.

For perfect majoritarian responsiveness, the slope of the estimated logit curve would be very steep at 50\% and go through the crosshair within each panel. Even when you have responsiveness, there are two ways to get incongruence then. The more obvious possibility is that the curve goes through the crosshairs but is insufficiently steep. The other way is policy bias: when the curve is shifted to the right of the crosshair, it means that a large level of liberal opinion (likely more than a majority) is needed to bring about policy adoption. This indicates a conservative bias in policymaking (underresponsiveness to liberal opinion). When the curve is to the left of the crosshairs, it indicates the opposite. Even a cursory glance at Figure 2 shows that we rarely observe perfect majoritarian control.

\section{Congruence and the Democratic Deficit}

As noted above, when policy responsiveness is weak or biased relative to majority opinion, the consequence is at least some incongruence. Indeed, our results show clear examples of strong responsiveness (a steep curve) coinciding with frequent mismatches between majority 
TABLE 1 The Democratic Deficit by State

\begin{tabular}{|c|c|c|c|c|c|c|c|c|}
\hline State & $\begin{array}{c}\text { Liberal } \\
\text { Policy } \\
(\%)\end{array}$ & $\begin{array}{c}\text { Liberal } \\
\text { Opinion } \\
(\%)\end{array}$ & $\begin{array}{c}\text { Liberal } \\
\text { Opinion } \\
\text { Majorities } \\
(\%)\end{array}$ & $\begin{array}{c}\text { Congruence } \\
(\%)\end{array}$ & $\begin{array}{l}\text { Liberal } \\
\text { Incong. } \\
\text { Bias }\end{array}$ & $\begin{array}{c}\text { Conservative } \\
\text { Incong. } \\
\text { Bias }\end{array}$ & $\begin{array}{c}\text { Net } \\
\text { Incong. } \\
\text { Bias }\end{array}$ & $\begin{array}{c}\text { Liberal } \\
\text { Incong. } \\
(\%)\end{array}$ \\
\hline California & 69 & 53 & 64 & 69 & 7 & 5 & 2 & 58 \\
\hline Louisiana & 31 & 46 & 41 & 69 & 4 & 8 & -4 & 33 \\
\hline Kansas & 44 & 45 & 46 & 62 & 7 & 8 & -1 & 47 \\
\hline Massachusetts & 64 & 55 & 62 & 62 & 8 & 7 & 1 & 53 \\
\hline Oklahoma & 21 & 41 & 41 & 59 & 4 & 12 & -8 & 25 \\
\hline Texas & 28 & 46 & 44 & 59 & 5 & 11 & -6 & 31 \\
\hline Arkansas & 21 & 44 & 38 & 56 & 5 & 12 & -7 & 29 \\
\hline Arizona & 31 & 49 & 49 & 56 & 5 & 12 & -7 & 29 \\
\hline Indiana & 31 & 45 & 44 & 56 & 6 & 11 & -5 & 35 \\
\hline Michigan & 38 & 49 & 51 & 56 & 6 & 11 & -5 & 35 \\
\hline Utah & 21 & 38 & 28 & 56 & 7 & 10 & -3 & 41 \\
\hline Wisconsin & 49 & 49 & 51 & 56 & 8 & 9 & -1 & 47 \\
\hline Georgia & 23 & 45 & 38 & 54 & 6 & 12 & -6 & 33 \\
\hline Idaho & 23 & 43 & 38 & 54 & 6 & 12 & -6 & 33 \\
\hline Missouri & 28 & 46 & 44 & 54 & 6 & 12 & -6 & 33 \\
\hline Washington & 72 & 52 & 62 & 54 & 11 & 7 & 4 & 61 \\
\hline Colorado & 59 & 51 & 56 & 51 & 10 & 9 & 1 & 53 \\
\hline Minnesota & 49 & 50 & 56 & 51 & 8 & 11 & -3 & 42 \\
\hline South Carolina & 26 & 45 & 38 & 51 & 7 & 12 & -5 & 37 \\
\hline Tennessee & 31 & 44 & 38 & 51 & 8 & 11 & -3 & 42 \\
\hline Connecticut & 72 & 52 & 62 & 49 & 12 & 8 & 4 & 60 \\
\hline Florida & 23 & 49 & 49 & 49 & 5 & 15 & -10 & 25 \\
\hline Illinois & 67 & 51 & 56 & 49 & 12 & 8 & 4 & 60 \\
\hline Maryland & 64 & 52 & 59 & 49 & 11 & 9 & 2 & 55 \\
\hline North Carolina & 31 & 46 & 41 & 49 & 8 & 12 & -4 & 40 \\
\hline New Jersey & 74 & 52 & 59 & 49 & 13 & 7 & 6 & 65 \\
\hline Ohio & 28 & 48 & 49 & 49 & 6 & 14 & -8 & 30 \\
\hline South Dakota & 33 & 45 & 44 & 49 & 8 & 12 & -4 & 40 \\
\hline Alabama & 26 & 42 & 38 & 46 & 8 & 13 & -5 & 38 \\
\hline Mississippi & 23 & 43 & 36 & 46 & 8 & 13 & -5 & 38 \\
\hline Nebraska & 36 & 44 & 44 & 46 & 9 & 12 & -3 & 43 \\
\hline New Mexico & 54 & 51 & 56 & 46 & 10 & 11 & -1 & 48 \\
\hline New York & 67 & 54 & 59 & 46 & 12 & 9 & 3 & 57 \\
\hline Rhode Island & 56 & 54 & 59 & 46 & 10 & 11 & -1 & 48 \\
\hline Virginia & 26 & 48 & 44 & 46 & 7 & 14 & -7 & 33 \\
\hline Iowa & 62 & 48 & 51 & 44 & 13 & 9 & 4 & 59 \\
\hline Maine & 59 & 52 & 59 & 44 & 11 & 11 & 0 & 50 \\
\hline North Dakota & 38 & 45 & 44 & 44 & 10 & 12 & -2 & 45 \\
\hline Kentucky & 41 & 44 & 48 & 41 & 12 & 11 & 1 & 52 \\
\hline Montana & 46 & 47 & 49 & 41 & 11 & 12 & -1 & 48 \\
\hline Nevada & 54 & 50 & 56 & 41 & 11 & 12 & -1 & 48 \\
\hline Hawaii & 64 & 52 & 59 & 38 & 13 & 11 & 2 & 54 \\
\hline Alaska & 46 & 47 & 49 & 36 & 12 & 13 & -1 & 48 \\
\hline Delaware & 44 & 52 & 56 & 36 & 10 & 15 & -5 & 40 \\
\hline Oregon & 62 & 51 & 59 & 36 & 13 & 12 & 1 & 52 \\
\hline
\end{tabular}


TABle 1 Continued

\begin{tabular}{lcccccccc}
\hline & $\begin{array}{c}\text { Liberal } \\
\text { Policy } \\
(\%)\end{array}$ & $\begin{array}{c}\text { Liberal } \\
\text { Opinion } \\
(\%)\end{array}$ & $\begin{array}{c}\text { Liberal } \\
\text { Opinion } \\
\text { Majorities } \\
(\%)\end{array}$ & $\begin{array}{c}\text { Congruence } \\
(\%)\end{array}$ & $\begin{array}{c}\text { Liberal } \\
\text { Incong. } \\
\text { Bias }\end{array}$ & $\begin{array}{c}\text { Conservative } \\
\text { Incong. } \\
\text { Bias }\end{array}$ & $\begin{array}{c}\text { Net } \\
\text { Incong. } \\
\text { Bias }\end{array}$ & $\begin{array}{c}\text { Liberal } \\
\text { Incong. } \\
(\%)\end{array}$ \\
\hline Vermont & 67 & 54 & 59 & 36 & 14 & 11 & 3 & 56 \\
New Hampshire & 59 & 51 & 59 & 33 & 13 & 13 & 0 & 50 \\
Pennsylvania & 38 & 50 & 54 & 33 & 10 & 16 & -6 & 38 \\
West Virginia & 36 & 46 & 46 & 33 & 11 & 15 & -4 & 42 \\
Wyoming & 36 & 44 & 46 & 33 & 11 & 15 & -4 & 42 \\
\hline min & 21 & 38 & 28 & 33 & 4 & 5 & -10 & 25 \\
max & 74 & 55 & 64 & 69 & 14 & 16 & 6 & 65 \\
mean & 44 & 48 & 49 & 48 & 9 & 11 & -2 & 44 \\
\hline
\end{tabular}

The first data column is the percentage of liberal policies by state (out of 39 total). The second is mean liberal opinion across policies by state. The third is the percentage of opinion majorities that are liberal. The fourth is the percentage of policies congruent with opinion majorities. The fifth and sixth are the counts of liberal and conservative policies that are incongruent, respectively. The final columns give the net bias from these and the percentage of the incongruence in the liberal direction.

will and policy, due to a biased policy curve. "Health Care: Medical Marijuana" and "Health Care: SCHIP" both show a significant positive relationship between opinion and policy and have similarly steep responsiveness curves. When plotted, however, the curve for the latter passes through the $50 \%$ crosshair while the former is shifted noticeably to the right. This shift means that support for medical marijuana has to be far above 50\% (approximately $70 \%$ ) to have a $50 \%$ chance of policy adoption. The consequence is that congruence for medical marijuana policy is relatively low-only $26 \%$ compared with $86 \%$ for SCHIP.

The percentages listed in each plot in Figure 2 are the share of states with policies that match the opinion majority (tick marks in the top-right and bottom-left quadrants are congruent). Congruence by policy and issue area is also shown in Table 2. Across policies, congruence ranges from 6\% ("Immigration: Bilingual") to $86 \%$ ("Gaming: Lottery"). The issue areas in which policy most frequently matches majority opinion are gay rights and gaming, which have congruence rates of $57 \%$ and $56 \%$, respectively. That we uncover such relatively high rates of congruence in these two areas seems to confirm the long-standing expectation that issues dealing with morality policy will be particularly responsive to public opinion (Mooney and Lee 1995). Indeed, if we group all policies that potentially address morality, we observe a congruence rate of $53 \%$ compared to $44 \%$ for all others. The issue area with the lowest congruence is immigration, where policy only matches majority opinion $33 \%$ of the time. There is also significant variation across states. Congruence by state (see Table 1 and the maps in Figure 1) ranges from 33\% (New Hampshire, inter alia) to $69 \%$ (California and Louisiana).
The bottom line is a great deal of incongruence in state policymaking. ${ }^{2}$ Despite the fact that policy is generally responsive to opinion, it only matches opinion $48 \%$ of the time. Especially for bare majorities, some incongruence might not be particularly worrisome (given that neither we nor political elites measure opinion perfectly) but the democratic deficit persists even with larger opinion majorities. For majorities of size $60 \%$ or larger, only $52 \%$ of policies are congruent. Even for majorities of $70 \%$, only $57 \%$ of policies are congruent. Limited congruence in the presence of responsiveness (which is what we typically observe) shows a limited degree of popular control-influence without sovereignty. ${ }^{3}$

Democracy delayed or democracy denied? One possibility is that the incongruence we observe is a temporal anomaly, with newer agenda items not yet in alignment with opinion. Baumgartner and Jones (1993) argue that

\footnotetext{
${ }^{2}$ Some argue that opinion follows policy (rather than vice versa). This would suggest that the "real" democratic deficit is even worse: some congruence occurs simply because people go along with their state policy or because people "vote with their feet," moving to states with policies they like. If this is true, the degree of incongruence we observe is even more surprising. Also, if people simply move in line with opinion, there should be even more congruence for older policies than we show below. In the SI, we explain further evidence against a "reverse causality" interpretation of our findings and explain why our reading of the literature supports our interpretation of our findings.

${ }^{3}$ One could observe congruence without an opinion-policy relationship or a negative one, in the presence of policy bias. For example, "Education: Standardized Tests" is still 54\% congruent despite the weak negative relationship between opinion and policy. "Law Enforcement: Assault Weapons" has far less congruence despite strong responsiveness because of the rightward shift of the curve. This sort of congruence without any responsiveness is epiphenomenal.
} 
TABle 2 The Democratic Deficit by Policy and Issue Area

\begin{tabular}{|c|c|c|c|c|c|c|c|c|c|}
\hline Issue Area & Policy & $\begin{array}{c}\text { Liberal } \\
\text { Policy } \\
(\%)\end{array}$ & $\begin{array}{c}\text { Liberal } \\
\text { Opinion } \\
(\%)\end{array}$ & $\begin{array}{c}\text { Liberal } \\
\text { Opinion } \\
\text { Majorities } \\
(\%)\end{array}$ & $\begin{array}{c}\text { Congruence } \\
(\%)\end{array}$ & $\begin{array}{c}\text { Liberal } \\
\text { Incong. } \\
\text { Bias }\end{array}$ & $\begin{array}{c}\text { Conserv. } \\
\text { Incong. } \\
\text { Bias }\end{array}$ & $\begin{array}{c}\text { Net } \\
\text { Incong. } \\
\text { Bias }\end{array}$ & $\begin{array}{c}\text { Liberal } \\
\text { Incong. } \\
(\%)\end{array}$ \\
\hline Gaming & lottery & 86 & 74 & 100 & 86 & 0 & 7 & -7 & 0 \\
\hline Health Care & SCHIP & 16 & 36 & 2 & 86 & 7 & 0 & 7 & 100 \\
\hline Immigration & driver's licenses & 16 & 22 & 0 & 84 & 8 & 0 & 8 & 100 \\
\hline Education & charter schools & 20 & 28 & 0 & 80 & 10 & 0 & 10 & 100 \\
\hline Gay Rights & adoption & 18 & 46 & 34 & 80 & 1 & 9 & -8 & 10 \\
\hline Gay Rights & marriage & 12 & 44 & 30 & 78 & 1 & 10 & -9 & 9 \\
\hline Elect. Reform & contrib. indiv. & 76 & 70 & 100 & 76 & 0 & 12 & -12 & 0 \\
\hline Elect. Reform & contrib. corp. & 74 & 59 & 100 & 74 & 0 & 13 & -13 & 0 \\
\hline Law Enforce. & death penalty & 28 & 29 & 0 & 72 & 14 & 0 & 14 & 100 \\
\hline Gay Rights & sodomy & 70 & 50 & 50 & 72 & 12 & 2 & 10 & 86 \\
\hline Abortion & notification & 30 & 24 & 0 & 70 & 15 & 0 & 15 & 100 \\
\hline Law Enforce. & concealed weapons & 20 & 50 & 50 & 70 & 0 & 15 & -15 & 0 \\
\hline Health Care & Medicaid access & 64 & 52 & 76 & 64 & 6 & 12 & -6 & 33 \\
\hline Gay Rights & hate crimes & 62 & 75 & 100 & 62 & 0 & 19 & -19 & 0 \\
\hline Law Enforce. & marijuana decrim. & 26 & 45 & 36 & 62 & 7 & 12 & -5 & 37 \\
\hline Abortion & counseling & 44 & 13 & 0 & 56 & 22 & 0 & 22 & 100 \\
\hline Education & standardized tests & 46 & 34 & 0 & 54 & 23 & 0 & 23 & 100 \\
\hline Gay Rights & civil unions & 24 & 56 & 72 & 52 & 0 & 24 & -24 & 0 \\
\hline Health Care & assisted suicide & 4 & 49 & 52 & 52 & 0 & 24 & -24 & 0 \\
\hline Abortion & parental consent & 50 & 25 & 0 & 50 & 25 & 0 & 25 & 100 \\
\hline Abortion & waiting period & 52 & 21 & 0 & 48 & 26 & 0 & 26 & 100 \\
\hline Gay Rights & employment & 40 & 67 & 98 & 42 & 0 & 29 & -29 & 0 \\
\hline Gay Rights & housing & 40 & 81 & 100 & 40 & 0 & 30 & -30 & 0 \\
\hline Elect. Reform & recall elections & 36 & 71 & 100 & 36 & 0 & 32 & -32 & 0 \\
\hline Education & vouchers & 86 & 49 & 30 & 36 & 30 & 2 & 28 & 94 \\
\hline Abortion & partial birth & 68 & 28 & 0 & 32 & 34 & 0 & 34 & 100 \\
\hline Gay Rights & health benefits & 28 & 64 & 98 & 30 & 0 & 35 & -35 & 0 \\
\hline Elect. Reform & term limits & 70 & 29 & 0 & 30 & 35 & 0 & 35 & 100 \\
\hline Gaming & casino & 22 & 58 & 92 & 26 & 1 & 36 & -35 & 3 \\
\hline Health Care & med. marijuana & 26 & 76 & 100 & 26 & 0 & 37 & -37 & 0 \\
\hline Law Enforce. & waiting period & 24 & 82 & 100 & 24 & 0 & 38 & -38 & 0 \\
\hline Law Enforce. & drug sentences & 22 & 57 & 98 & 24 & 0 & 38 & -38 & 0 \\
\hline Immigration & verify & 78 & 31 & 0 & 22 & 39 & 0 & 39 & 100 \\
\hline Law Enforce. & assault weapons & 20 & 60 & 100 & 20 & 0 & 40 & -40 & 0 \\
\hline Health Care & stem cell & 20 & 62 & 100 & 20 & 0 & 40 & -40 & 0 \\
\hline Immigration & tuition & 18 & 57 & 100 & 18 & 0 & 41 & -41 & 0 \\
\hline Education & affirmative action & 90 & 43 & 8 & 14 & 42 & 1 & 41 & 98 \\
\hline Elect. Reform & photo ID & 86 & 18 & 0 & 14 & 43 & 0 & 43 & 100 \\
\hline Immigration & bilingual & 94 & 40 & 0 & 6 & 47 & 0 & 47 & 100 \\
\hline Gay Rights & & 37 & 60 & 73 & 57 & 14 & 158 & -144 & 8 \\
\hline Gaming & & 54 & 66 & 96 & 56 & 1 & 43 & -42 & 97 \\
\hline Abortion & & 49 & 22 & 0 & 51 & 122 & 0 & 122 & 100 \\
\hline Health Care & (all policies) & 26 & 55 & 66 & 50 & 13 & 113 & -100 & 10 \\
\hline Education & & 61 & 38 & 10 & 46 & 105 & 3 & 102 & 97 \\
\hline Elect. Reform & & 68 & 49 & 60 & 46 & 78 & 57 & 21 & 58 \\
\hline Law Enforce. & & 23 & 54 & 64 & 45 & 21 & 143 & -122 & 13 \\
\hline Immigration & & 52 & 37 & 25 & 33 & 94 & 41 & 53 & 70 \\
\hline
\end{tabular}

The first data column is the percentage of liberal policies by policy (across the 50 states). The second is mean liberal opinion across states by policy. The third is the percentage of opinion majorities that are liberal. The fourth is the percentage of policies congruent with opinion majorities. The fifth and sixth are the counts of liberal and conservative policies that are incongruent, respectively. The final columns give the net bias from these and the percentage of the incongruence that is in the liberal direction. The bottom section of the table does the same by issue area. 
FIGURE 1 Distribution of Policy and Opinion Majorities

\section{Liberal Opinion Majorities}

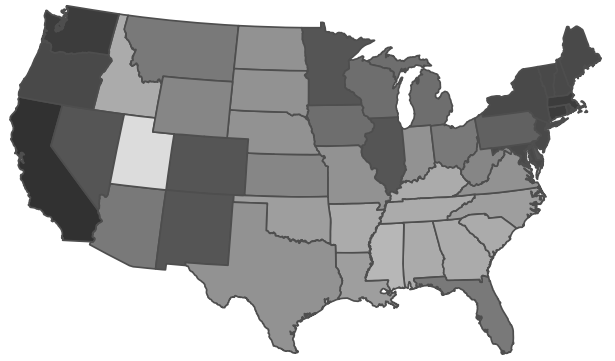

Liberal Policies

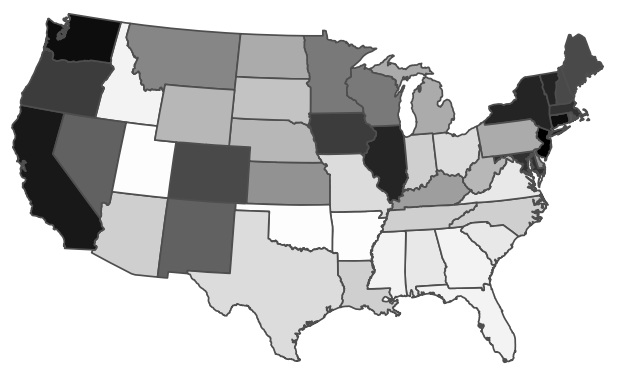

Congruence

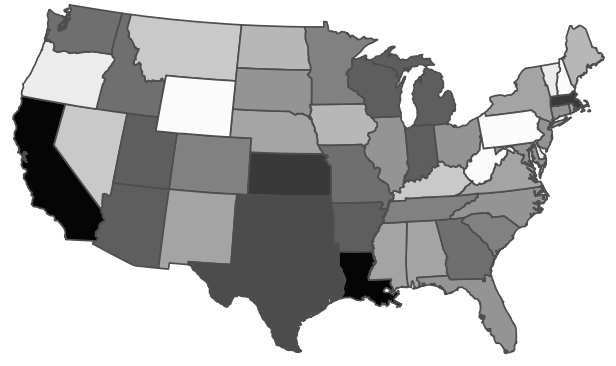

Net Liberal Incongruence

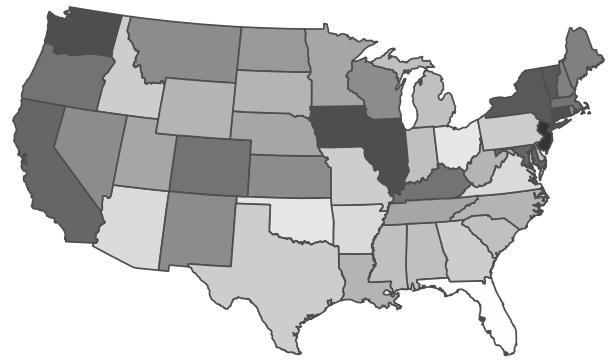

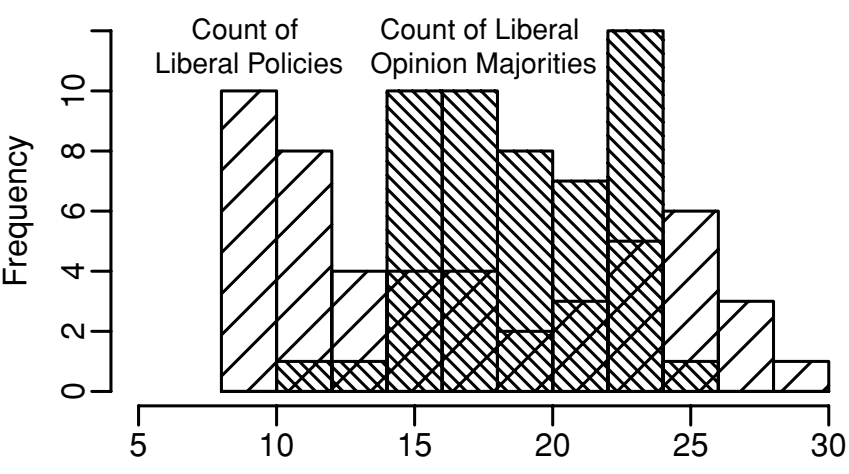

Number of Policies by State
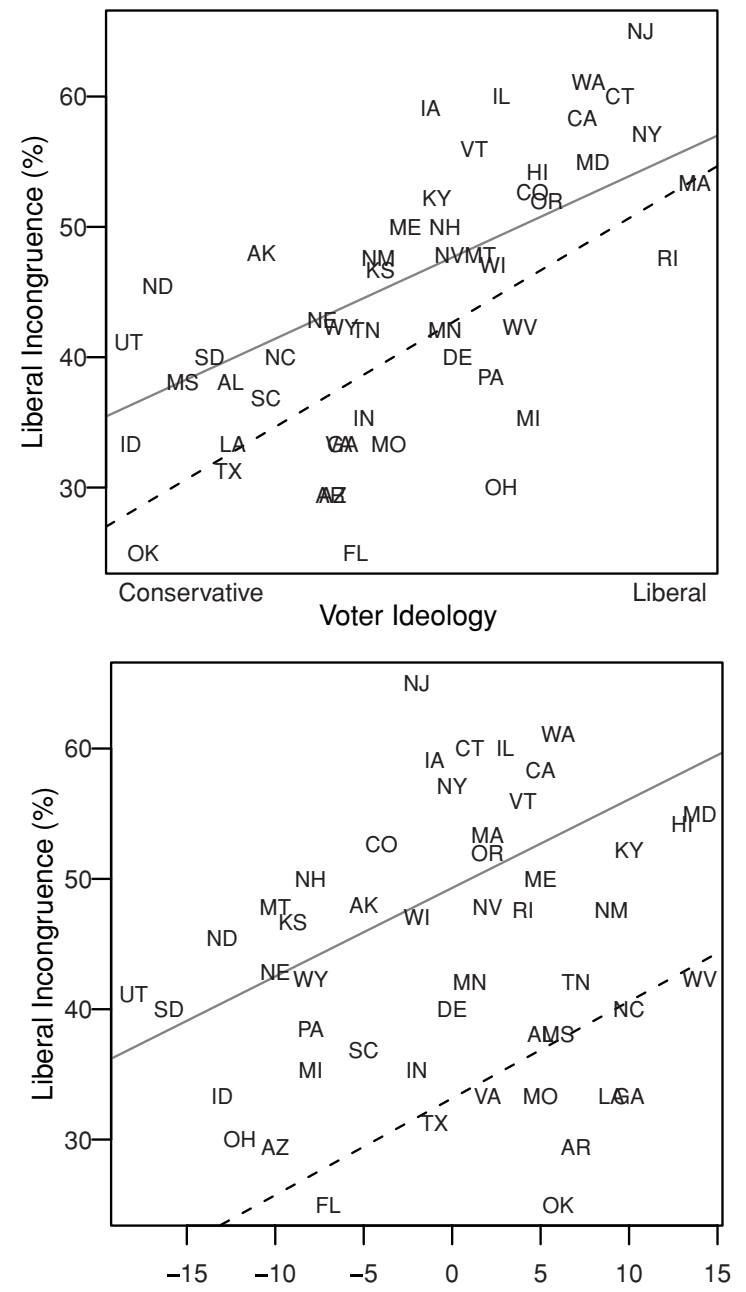

Count of Years of Unified Democratic Control

- Years of Unified Republican Control

The maps show the number of liberal opinion majorities (darker = liberal; Montana is at the median), number of policies that are liberal (darker = liberal; Pennsylvania is at the median), number of policies that are congruent (darker = congruent; Florida is at the median), and the net liberal incongruence policy bias (darker = liberal; Maine is balanced). The histogram shows the distribution of counts of liberal opinion majorities and of liberal policies. The remaining panels on the lower right show the percentage of incongruence that is liberal for each state against state voter ideology and then against partisan control of government. The dashed regression line shows the southern states and the solid line the rest. 


\section{FIGURE 2 Basic Relationships}
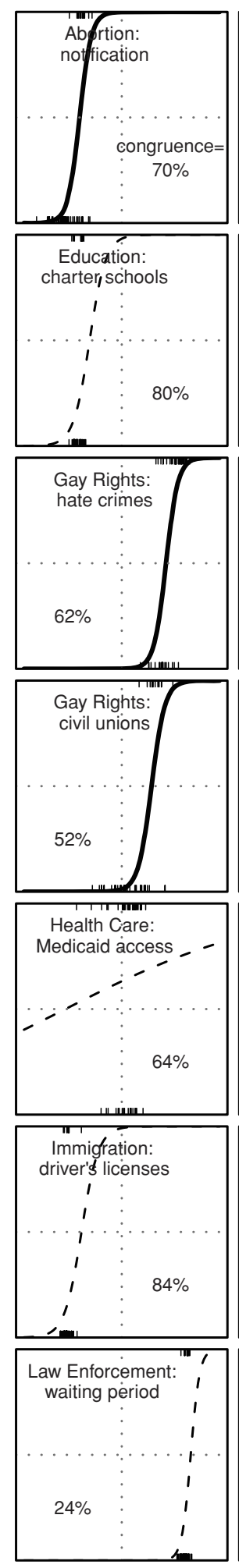
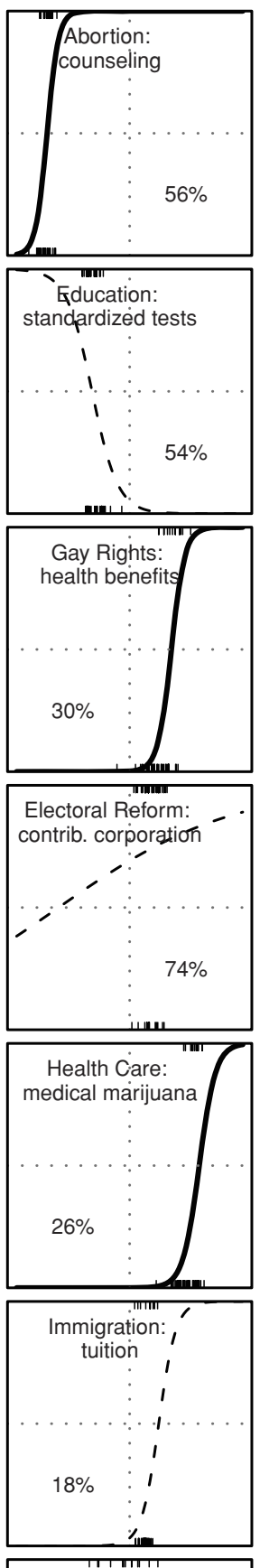

Law Enforcement:
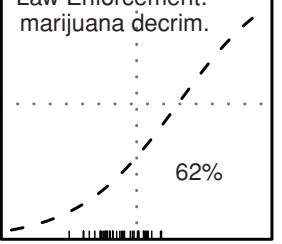
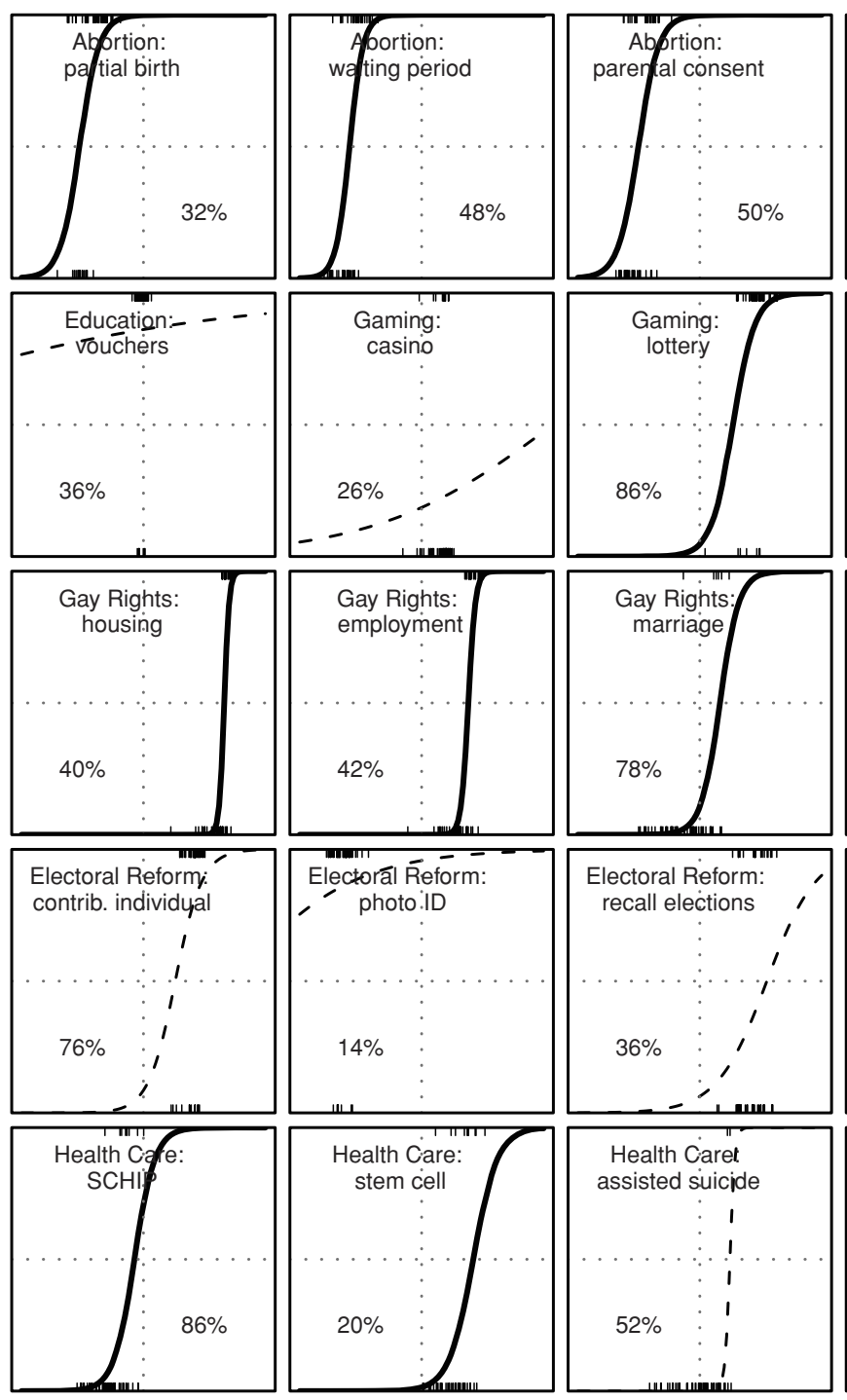

Imlmigration:

verify

1

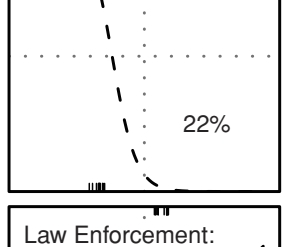

Law Enforcem

assault weappns

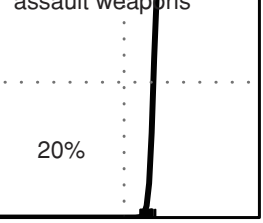

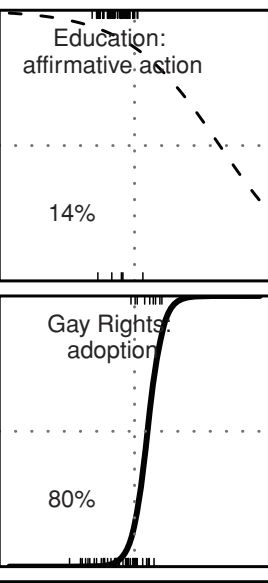

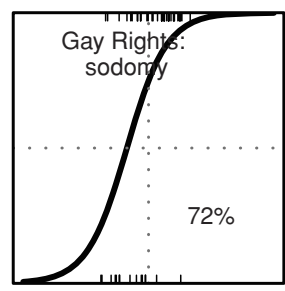

El

term liṃnits

,
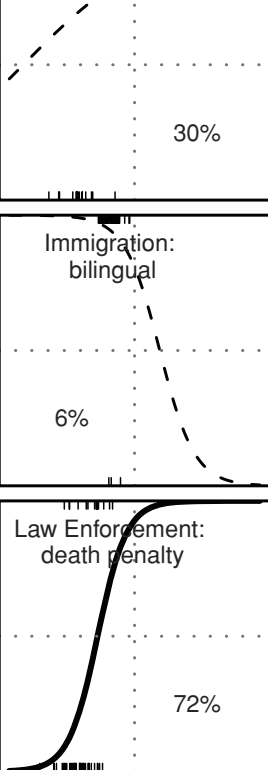

drug sentences

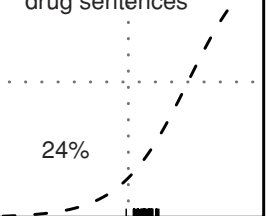

Each graph plots the probability of policy adoption from a logistic regression curve given state opinion. Each $\mathrm{x}$ - and $\mathrm{y}$-axis runs from 0 to $100 \%$ for opinion and the probability of policy adoption, respectively. Opinion in states with the policy in question are plotted (in a "rug") on the top axis and those without on the bottom. Dotted lines show the 50\% marks in opinion support and policy probability. Panels are ordered by policy group. Bold solid lines indicate a relationship significant at $95 \%$ (two-tailed). The percentage in each panel is the degree of congruence across states between the policy and the opinion majority (rug marks in the top-right and bottom-left quadrants are congruent). 
policymaking is an evolutionary process: change is slow and new issues create instability, taking time to move into equilibrium. Of policies that have largely entered state policy agendas during the last decade or so, only $46 \%$ are congruent, compared to $50 \%$ for all remaining policies. This is compatible with the view that it takes time for policy to move into congruence with opinion. On the other hand, that so much incongruence remains even for policies that have long been on state agendas (e.g., recall elections, gun restrictions, etc.) suggests strongly that the democratic deficit we document is not simply a short-run phenomenon.

Polarized Policy, Unpolarized Voters. Incongruence can occur when policy is liberal and the opinion majority is conservative or vice versa-and so the direction of incongruence can vary and not just the extent thereof. When the policy curve goes through the 50-50 crosshair but is insufficiently steep, incongruence will be balanced between the liberal and conservative directions. When the curve does not hit this crosshair, incongruence will not be so balanced, and indeed this is what we usually observe. The ideological tendency of state incongruence is shown in the rightmost columns of Tables 1 and 2 (also see the bottom map in Figure 1). Of overall incongruence, 55\% is conservative in direction, suggesting a conservative bias relative to opinion majorities. The opinion majority is conservative and policy liberal 448 times (of 1,950 state-policy comparisons); the opinion majority is liberal and policy conservative 558 times (so net bias due to incongruence is 110 conservative policies). ${ }^{4}$

At first glance, the ideological direction of incongruence correlates to the popular "red" versus "blue" state division of conservative and liberal states: see the bottomleft map in Figure 1, which shades states based on net liberal incongruence (e.g., a liberal state like Washington is quite dark because it has four more liberal incongruent policies than conservative incongruent policies; Oklahoma, a conservative state, is much lighter because it has eight more conservative incongruent policies than it has liberal incongruent policies). Indeed, the middle-right graph in Figure 1 shows that the percentage of incongruence that is liberal correlates to voter ideology (we develop this analysis later).

In fact, blue states tend to go "too far" in adopting liberal policies and the red states go "too far" in the other direction. The consequences can be seen in simple counts of

\footnotetext{
${ }^{4}$ For supermajorities of size $60 \%$ or more (1,307 state-policy comparisons), we see a different picture: $54 \%$ of incongruence is in the liberal direction, and the net bias due to incongruence is 52 policies in the liberal direction. This suggests that smaller liberal opinion majorities are being frustrated in comparison to larger conservative opinion majorities.
}

liberal opinion majorities and liberal policies. Histograms of these counts are shown in the top right of Figure 1. The policy count histogram is bimodal and spread out relative to the more concentrated (darkly shaded) opinion count. All but two states have between 15 and 25 liberal opinion majorities, yet 29 states have liberal policy counts outside this central region. That is, two states are "extreme" in the number of liberal opinion majorities and 29 are "extreme" in actual policy. Of these 29, 22 lie outside this range by being more conservative than the moderate region; seven lie outside to the liberal side. ${ }^{5}$ To put it simply, policy is polarized relative to public opinion, which varies much less across states. This polarization can also be seen by comparing the top-left policy and opinion maps in Figure 1 . There are many states with middling gray levels of opinion liberalism, whereas the policy maps show a clearer split between light and dark states. (The lighter tone overall suggests a slight conservative policy bias.)

Our findings are consistent with a world in which states implement either a largely liberal or largely conservative slate of policies, rather than a policy-by-policy median voter world, in which it is possible to mix and match policies as preferred by opinion majorities. This polarization also suggests that incongruence is not random error, but rather systematic.

\section{Explaining Variation in Responsiveness and Congruence}

We now explore factors that potentially shape responsiveness and congruence, starting with salience.

Salience. The strength of the opinion-policy linkage should be conditioned by the salience of the policy, that is, its importance to the public and its prominence in public discourse. For salient policies, citizens are more likely to hold strong opinions, to convey those opinions to their representatives, and to hold their representatives accountable (Page and Shapiro 1983). When salience is low, however, officials may be unaware of their constituents' preferences, and so might follow cues such as ideology to fill in the gaps (Druckman and Jacobs 2006). Finally, by giving voters what they want on salient policies, legislators may be more free in making other less salient policy choices, so long as they are responsive "enough."

To measure Salience, we conducted a Proquest search of New York Times articles counting how often the policy was mentioned in some form (details available by

\footnotetext{
${ }^{5}$ For a moderate region of 17 to 22,25 states are extreme in opinion and 41 in policy.
} 
request), averaging within each issue area, and taking the log number of such stories. Although obviously crude, this technique performs reasonably well, and similar measures have been used with success (Haider-Markel and Meier 1996; Lax and Phillips 2009b). It is not designed to capture variation in state media coverage; such coverage might be endogenous to policy adoption by state, whereas the national measure will more cleanly capture the relative visibility of each issue. The specific issues we study vary widely in terms of their salience. Some, such as same-sex marriage laws and abortion restrictions, have been at the center of recent political conflict in the United States, whereas others have been less important (though none have been entirely absent from media coverage or state policy agendas).

Ideology. As we noted, politicians might cue off of voter ideology in lieu of specific policy preferences, and they no doubt want to fulfill their own ideological goals. Thus, we compare the impact of policy-specific Opinion estimates against voter and government ideology. Voter Liberalism is based on Erikson, Wright, and McIver's ideology scores (1993): the self-identified liberalism/conservatism of voters in national survey data. Opinion does not reduce to ideology, though they do correlate. This relationship varies by policy (mean correlation is .56, ranging from -.83 for charter schools to +.83 for stem cell). Also, while every state has more self-identified conservatives than liberals, $49 \%$ of opinion majorities are liberal. Government Liberalism is the Berry et al. (1998) ideology score for state elected officials, based on the partisan configuration of state government and interest group ratings of the state congressional delegation (averaged 1995-2005). Higher numbers on both scores are more liberal.

Institutions. Many of the largest debates in the state politics literature involve which, if any, institutional features of state government enhance or undercut the relationship between policy and opinion. One feature is the citizen initiative, which exists in 24 states. There are two ways it might enhance the effects of opinion. First, when a majority of voters prefer an alternative policy to that of the status quo, they can circumvent elected officials and enact their preferred policy outright. Second, the initiative may function as a "gun behind the door," even if it is never used. Interest groups or citizens can, in response to legislative inaction or unpopular legislation, threaten to pursue their policy goals via the initiative. This threat may then spur elected officials to make changes in their policy choices as a means of avoiding a ballot measure. Even in the absence of an explicit threat, officials may anticipate the behavior of potential initiative authors and draft laws in a manner that preempt future ballot measures. Both effects are likely to be median enhancing (Gerber 1996, 1999).

Some disagree, given the costs of the initiative process; the role that interest groups play in writing, qualifying, and financing ballot measures; and the limited understanding that voters have of policy questions on which they are asked to vote (Lascher, Hagen, and Rochlin 1996). Some studies find evidence supporting the initiative effect, at least in some policy areas (Arceneaux 2002; Gerber 1996, 1999; Matsusaka 2010; Phillips 2008), whereas others do not find an effect (Monogan, Gray, and Lowery 2009; Lascher, Hagen, and Rochlin 1996; Lax and Phillips 2009b). Our policy-specific opinion measures might help resolve this thorny debate. Citizen Initiative is an indicator for states that allow either constitutional or statutory citizen initiatives.

Next, we expect that legislative professionalization will enhance the effects of public opinion. Some states use highly professional chambers that resemble the U.S. House of Representatives (e.g., California and New York), whereas others rely on "citizen" chambers (e.g., New Hampshire). Professionalized legislatures are well paid, meet in lengthy sessions, and employ numerous nonelected staff. This allows lawmakers to treat their legislative service as a career. In citizen chambers, in contrast, the number of days legislators are allowed to meet is often constitutionally restricted (in extreme cases, 60 or 90 days biennially); compensation is low; there are few staff; and legislators hold outside jobs. Professional chambers should have a greater capacity and resources to assess and respond to public opinion. Longer sessions allow them to consider more issues, including those of relatively lower salience, and outside employment is less likely to constrain attention to constituents. Seats in professional chambers are also more valuable, so there are greater incentives for lawmakers to be responsive (Maestas 2000). We thus expect to see greater responsiveness and more congruence in states with professionalized legislatures.

On the other hand, some argue that professionalization leads to elite capture of the governing apparatus (Weber 1999) and that citizen legislatures will be more in touch with the people. Still, we are not aware of any systematic evidence that professionalization undercuts the link between the people and policy. Our Legislative Professionalization measure comes from Squire (2007). It is a weighted combination of salary, days in session, and staff per legislator, as compared to those in Congress the same year.

Next, term limits may reduce the capacity of lawmakers to assess and respond to opinion by reducing experience (Kousser 2005) and may reduce incentives to respond 
to public opinion by limiting the value of a legislative seat. On the other hand, as proponents of term limits argue, to the extent term limits induce greater turnover, they might lead to legislators who better reflect current constituents' preferences directly and might reduce the extent to which legislators are "captured" by interest groups or political insiders. Additionally, they might shift a legislator's attention to future statewide races (Carey, Niemi, and Powell 2000). Term Limits is our indicator for states that currently have such limits for legislative office.

Finally, we also might expect to observe greater responsiveness and congruence in states that elect their high court judges ( 39 states require judges to be approved by voters via a partisan, nonpartisan, or retention election). Judicial decisions on important social issues often play a significant role in such elections. Elected Court is our indicator for states that elect the judges in their highest court (including partisan, nonpartisan, and retention elections; other codings yielded the same findings).

Interest Groups. All states have numerous interest groups, with hundreds or even thousands of registered lobbyists, representing a wide array of economic and social concerns (Lowery and Gray 1995, 2004). The political power of these groups varies strongly across states (Thomas and Hrebenar 2008). To be sure, interest groups need not be seen as purely counterdemocratic. These groups can even strengthen the effect of opinion. There can be policies for which lawmakers are unaware of constituent opinion. Furthermore, given limitations on agenda space, lawmakers simply may not have the time to consider all policies preferred by voters. Organized interests can act as information providers and can use their resources to pressure lawmakers to place popular measures on the agenda. They can also undertake activities to raise the salience of a particular policy. In direct democracy states, they can circumvent the legislature entirely and pursue popular measures via the initiative process. All of these could strengthen the policy-opinion relationship.

On the other hand, powerful interest groups may use their resources to block popular policies, and elected officials may be pressured to satisfy such groups instead of the median voter (to garner campaign contributions or other types of support). Overall, we expect that responsiveness and congruence will be conditioned by the net balance of powerful interest groups in a state targeting a particular policy. When the interest group and the popular majority are aligned, we should expect greater policy congruence than when the two are opposed. If there are such groups on both sides, they can cancel out.

Powerful Interest Group Balance captures whether there is a powerful interest group in the state pushing for the liberal policy $(+1)$ or conservative policy $(-1)$. Specif- ically, the score is the sum of these forces within a state on a policy (so it ranges from -1 to 1 , with opposing groups canceling out at 0 ). First, we identified powerful interest groups using an updated list by Thomas and Hrebenar (2008, original list), which provides an expert qualitative evaluation of interest groups by state. We then identified which of them would normally be associated with each policy, and likely position on them (see the SI). For example, we code the pharmaceutical industry ("powerful" in eight states) as preferring to allow stem cell research; and social conservative groups ("powerful" in 24 states) to oppose it. Given overlap, four states get scored $+1 ; 20$ at -1 ; and 26 at 0 (due to neither or both being powerful in the state).

Party Politics. Finally, there is the role of elite party politics, namely the impact of party control of the legislature and governorship. We would expect that the stronger the hold of the Republican (Democratic) party on the state government, the more conservative (liberal) state policy will be, holding policy support constant. When party pressures and public preferences both push for a particular policy, we should be far more likely to see congruence. Besides party, we also control for the ideological liberalness of state governments. Closely related to partisan control is electoral competition. When one party dominates the electoral landscape, monopolizing the reins of government, we would expect public influence to be more limited than when the parties are actively competing for support.

We calculated the Democrats' mean share of state legislative seats (averaging the two chambers) over the period 1990 to 2007, as well as the amount of time they controlled the governorship in each state. We call these Democratic Legislature \% and Democratic Governor \%. We next calculate, by state, the number of years of unified Democratic control and the number of years of unified Republican control. One-Party Dominance is the absolute value of the difference between them (a state has a low score if it rarely has unified government or does have it but party control flips back and forth; if it usually has unified partisan control by one party and not the other, it will have a high score).

Finally, we control for another aspect of political context, Turnout averaged over the last three presidential elections (broader participation might induce greater congruence).

\section{Results}

Explaining Responsiveness and Congruence. We move now to multilevel logistic regression models of responsiveness and congruence. For congruence models, 
we use Size of Majority (from 50\% to 100\%). The larger the opinion majority, the stronger the signal sent to political actors, and so the greater the likelihood of congruence. Variables coded with an ideological direction in congruence regressions are centered and flipped around their means as necessary so that coding is in the direction opposite that of the opinion majority (e.g., for a conservative opinion majority, greater voter liberalism is coded as negative). When the scores are positive, they make congruence less likely; when negative, they point in the same direction as the opinion majority, making congruence more likely. These predictors are then labeled as Opposition (e.g., Voter Ideological Opposition). We standardize continuous variables to compare relative impact: a one-unit change is a two standard deviation shift for each variable, and each is centered at its mean. Continuous predictors and dichotomous ones are now roughly on the same scale, and the "base" term given an interaction effect shows the effect at the average value of the interacted predictor, when it takes the value zero and thus drops out. See the SI for an assortment of robustness checks and supplemental results.

For responsiveness, the dependent variable is an indicator for whether each state policy is liberal, and a key independent variable can be an interaction between a predictor and an opinion. This captures whether there is more or less responsiveness to opinion (a steeper or more shallow slope) under different conditions. For congruence models, the dependent variable is an indicator for the state policy matching the opinion majority. Interactions are not necessary as the predictors are directly related to congruence. Those predictors that were not interacted in the responsiveness models, however, must for congruence be oriented properly in terms of direction with the opinion majority. That is, for responsiveness, we ask whether term limits increase the slope of policy with respect to opinion; for congruence, we ask whether term limits increase or decrease the absolute likelihood of having congruence.

Tables 3 and 4 show the full results. We show results from six model variants, to check robustness across specifications. For each table, Model 1 includes only opinion and salience; Model 2 adds voter ideology; Model 3 adds government ideology and partisanship measures; Model 4 instead uses institutional variables; Model 5 instead uses political context variables; and Model 6, the main model, includes all the variables except for Elected Court (we explain why below). For both responsiveness and congruence, the most complete model has the best fit. Findings remain robust to these and other variations (including limiting analysis to only larger states, for which one might expect the most precise opinion estimates).
The basic relationship between policy and opinion is very clear: states with a higher level of policy support are far more likely to have the policy. All responsive models show that policy-specific opinion has a significant and strong effect on policy adoption independent of elected elites, voter ideology (liberalism), and other factors; all congruence models show the strong impact of majority size. The average effect of policy-specific opinion is over twice that of diffuse voter ideology. The latter still has a substantively and statistically significant effect on policy and congruence. Consistent with our expectations, higher salience does increase the impact of policy-specific opinion, as shown by the large interaction term. At average/zero values, one additional point of policy-specific opinion increases the chance of policy adoption by close to two percentage points. Salience one standard deviation above average almost doubles that (SI Figure 4 compares effect sizes). When the state government is more liberal and under Democratic control more of the time, liberal opinion majorities are more likely to get what they want. Government liberalism (but not party control in the responsiveness model) operates as predicted. ${ }^{6}$

Of the institutions, only legislative professionalization and term limits enhance responsiveness. The interaction terms show substantively and statistically significant effects on the marginal effect of opinion (increasing the responsiveness slope) and similar effects on congruence. A one standard deviation increase in professionalization increases the marginal effect of opinion by about $28 \%$ (the shift in congruence is 5 percentage points over this range). Term limits increase the marginal impact of opinion by $44 \%$ and increase the probability of congruence by up to 15 percentage points. We explored professionalization further, showing that it operates primarily through increasing agenda space rather than through salary or staff resources (see SI). Elected courts seem to increase responsiveness and congruence, but we find this effect to be spurious. When we control for policy areas in which court involvement is more likely, there is no increased responsiveness when courts are elected (the coefficient approaches zero), but rather only in areas where courts are not usually involved. The citizen initiative does not enhance responsiveness (indeed it is incorrectly signed; alternative measures leading to the same conclusion are explored in the SI). To be sure, only Louisiana has term limits without also having direct democracy, and $61 \%$ of states with direct democracy have term limits. This suggests that the direct democracy might have an

\footnotetext{
${ }^{6}$ Party control effects for responsiveness are in the wrong direction, likely due to both multicollinearity and, as we will see later, what has often been called "southern distinctiveness."
} 
TABle 3 Policy Responsiveness Models

\begin{tabular}{|c|c|c|c|c|c|c|}
\hline \multicolumn{7}{|c|}{ Policy Responsiveness (Does the State Have the Liberal Policy?) } \\
\hline & 1 & 2 & 3 & 4 & 5 & 6 \\
\hline \multicolumn{7}{|l|}{ Voter Preferences } \\
\hline Opinion & $4.7^{* *}$ & $3.2^{* *}$ & $2.8^{* *}$ & $3.1^{* *}$ & $2.9^{* *}$ & $2.6^{* *}$ \\
\hline & $(.8)$ & $(.7)$ & (.7) & $(.7)$ & $(.6)$ & $(.7)$ \\
\hline Salience $\times$ Op. & $2.9^{* *}$ & $2.5^{* *}$ & $2.2^{* *}$ & $2.4^{* *}$ & $2.3^{* *}$ & $2.0^{*}$ \\
\hline & $(1.5)$ & $(1.3)$ & $(1.4)$ & $(1.4)$ & $(1.2)$ & $(1.3)$ \\
\hline Voter Liberalism & & $\begin{array}{l}1.3^{* *} \\
(.2)\end{array}$ & $\begin{array}{l}1.0^{* *} \\
(.2)\end{array}$ & $\begin{array}{l}1.4^{* *} \\
(.2)\end{array}$ & $\begin{array}{l}1.2^{* *} \\
(.2)\end{array}$ & $\begin{array}{l}1.1^{* *} \\
(.2)\end{array}$ \\
\hline \multicolumn{7}{|l|}{ Elite Preferences and Party } \\
\hline Govt. Liberalism & & & $\begin{array}{l}1.2^{* *} \\
(.4)\end{array}$ & & & $\begin{array}{l}.8^{* *} \\
(.4)\end{array}$ \\
\hline Democratic Legislature \% & & & $\begin{array}{r}-1.0 \\
(.3)\end{array}$ & & & $\begin{array}{r}-.6 \\
(.3)\end{array}$ \\
\hline Democratic Governor \% & & & $\begin{array}{c}-.4 \\
(.2)\end{array}$ & & & $\begin{array}{l}-.3 \\
(.2)\end{array}$ \\
\hline \multicolumn{7}{|l|}{ Institutional Interactions } \\
\hline Professionalization $\times$ Op & & & & $\begin{array}{l}.7^{* *} \\
(.2)\end{array}$ & & $\begin{array}{l}.7^{* *} \\
(.3)\end{array}$ \\
\hline Term Limits $\times$ Op & & & & $\begin{array}{l}1.0^{* *} \\
(.3)\end{array}$ & & $\begin{array}{l}1.2^{* *} \\
(.3)\end{array}$ \\
\hline Citizen Init. $\times$ Op. & & & & $\begin{array}{c}-.5 \\
(.3)\end{array}$ & & $\begin{array}{l}-.4 \\
(.3)\end{array}$ \\
\hline Elected Court $\times$ Op. & & & & $\begin{array}{l}.2 \\
(.3)\end{array}$ & & \\
\hline \multicolumn{7}{|l|}{ Int. Grps. and Pol. Context } \\
\hline Powerful Int. Group Balance & & & & & $\begin{array}{l}.5^{* *} \\
(.2)\end{array}$ & $\begin{array}{l}.5^{* *} \\
(.2)\end{array}$ \\
\hline Turnout $\times$ Op & & & & & $\begin{array}{l}-.1 \\
(.3)\end{array}$ & $\begin{array}{l}.02 \\
(.3)\end{array}$ \\
\hline One-Party Dominance $\times$ Op & & & & & $\begin{array}{c}-.3 \\
(.3)\end{array}$ & $\begin{array}{c}-.2 \\
(.3)\end{array}$ \\
\hline \multicolumn{7}{|l|}{ Base Terms and Intercepts } \\
\hline Intercept & $-1.1(.5)$ & $-1.0(.4)$ & $-1.0(.4)$ & $-.9(.5)$ & $-.8(.4)$ & $-.7(.4)$ \\
\hline Salience & $-2.9^{* *}(1.0)$ & $-2.3^{* *}(.8)$ & $-2.1^{* *}(.8)$ & $-2.4^{* *}(.8)$ & $-2.0^{* *}(.8)$ & $-2.0^{* *}(.8)$ \\
\hline Professionalization & & & & $-.2(.2)$ & & $-.2(.2)$ \\
\hline Term Limits & & & & $-.4^{*}(.2)$ & & $-.2(.2)$ \\
\hline Citizen Init. & & & & $.2(.2)$ & & $.0(.2)$ \\
\hline Elected Court & & & & $.2(.3)$ & & \\
\hline Turnout & & & & & $.4^{* *}(.2)$ & $.3^{*}(.2)$ \\
\hline One-Party Dominance & & & & & $.0(.2)$ & $.0(.2)$ \\
\hline State intercepts (st. dev.) & .7 & .5 & .4 & .4 & .4 & .3 \\
\hline State opinion slopes (st. dev.) & .4 & .4 & .4 & .0 & .3 & .0 \\
\hline Policy intercepts (st. dev.) & 2.9 & 2.3 & 2.2 & 2.3 & 2.1 & 2.1 \\
\hline Policy opinion slopes (st. dev.) & 3.6 & 3.0 & 3.1 & 3.0 & 2.6 & 2.7 \\
\hline Deviance Info. Criterion (DIC) & 1969 & 1935 & 1878 & 1912 & 1916 & 1842 \\
\hline
\end{tabular}

All are multilevel logistic regression (logit) models with varying intercepts and slopes for opinion by policy and by state. Continuous variables are standardized (subtracting the mean and dividing by two standard deviations, putting them on the same scale as each other and roughly the same scale as the dichotomous variables). $\mathrm{N}=1,950$, except for models with partisan legislature, which drop Nebraska's 39 observations. Directional predictions use one-tailed tests: ${ }^{*}<.10,{ }^{* *}<.05$. 
TABLE 4 Policy Congruence Models

\begin{tabular}{|c|c|c|c|c|c|c|}
\hline \multicolumn{7}{|c|}{ Policy Congruence (Is State Policy Congruent with the Opinion Majority?) } \\
\hline & 1 & 2 & 3 & 4 & 5 & 6 \\
\hline \multicolumn{7}{|l|}{ Voter Preferences } \\
\hline \multirow[t]{2}{*}{ Size of Opinion Majority } & $2.9^{* *}$ & $1.9^{* *}$ & $1.8^{* *}$ & $1.9^{* *}$ & $1.8^{* *}$ & $1.7^{* *}$ \\
\hline & $(.5)$ & $(.4)$ & $(.4)$ & $(.4)$ & $(.4)$ & $(.4)$ \\
\hline \multirow[t]{2}{*}{ Salience } & $1.2^{* *}$ & $.8^{*}$ & $.8^{*}$ & $.8^{*}$ & $.8^{* *}$ & $.8^{* *}$ \\
\hline & $(.6)$ & $(.5)$ & $(.5)$ & $(.5)$ & $(.5)$ & $(.5)$ \\
\hline \multirow[t]{2}{*}{ Conservative Opinion Majority } & $1.2^{* *}$ & $1.2^{* *}$ & $1.3^{* *}$ & $1.3^{* *}$ & $.9^{* *}$ & 1.2 \\
\hline & $(.2)$ & $(.2)$ & $(.2)$ & $(.2)$ & $(.2)$ & $(.2)$ \\
\hline \multirow[t]{2}{*}{ Voter Ideological Opposition } & & $-1.0^{* *}$ & $-.8^{* *}$ & $-1.1^{* *}$ & $-1.0^{* *}$ & $-.9^{* *}$ \\
\hline & & $(.1)$ & $(.2)$ & $(.1)$ & $(.1)$ & $(.2)$ \\
\hline \multicolumn{7}{|l|}{ Elite Preferences } \\
\hline \multirow[t]{2}{*}{ Govt. Ideological Opposition } & & & $-1.1^{* *}$ & & & $-1.1^{* *}$ \\
\hline & & & $(.3)$ & & & $(.3)$ \\
\hline \multirow[t]{2}{*}{ Legislative Partisan Opposition } & & & $-.9^{* *}$ & & & $-.8^{* *}$ \\
\hline & & & $(.2)$ & & & $(.2)$ \\
\hline \multirow[t]{2}{*}{ Governor Partisan Opposition } & & & $-.3^{* *}$ & & & $-.3^{*}$ \\
\hline & & & $(.2)$ & & & $(.2)$ \\
\hline \multicolumn{7}{|l|}{ Institutions } \\
\hline \multirow[t]{2}{*}{ Professionalization } & & & & $.4^{* *}$ & & $.4^{* *}$ \\
\hline & & & & $(.1)$ & & $(.1)$ \\
\hline \multirow[t]{2}{*}{ Term Limits } & & & & $.5^{* *}$ & & $.6^{* *}$ \\
\hline & & & & $(.2)$ & & $(.2)$ \\
\hline \multirow[t]{2}{*}{ Citizen Init. } & & & & -.3 & & -.2 \\
\hline & & & & $(.2)$ & & $(.2)$ \\
\hline \multirow[t]{2}{*}{ Elected Court } & & & & $.3^{*}$ & & \\
\hline & & & & $(.1)$ & & \\
\hline \multicolumn{7}{|l|}{ Political Context } \\
\hline \multirow[t]{2}{*}{ Interest Group Opposition } & & & & & $-.7^{* *}$ & $-.7^{* *}$ \\
\hline & & & & & $(.1)$ & $(.1)$ \\
\hline \multirow[t]{2}{*}{ Turnout } & & & & & -.1 & -.1 \\
\hline & & & & & $(.1)$ & $(.1)$ \\
\hline \multirow[t]{2}{*}{ One-Party Dominance } & & & & & -.2 & -.1 \\
\hline & & & & & $(.2)$ & -0.1 \\
\hline Intercept & $-1.0(.3)$ & $-1.0(.3)$ & $-1.0(.3)$ & $-1.2(.3)$ & $-.8(.3)$ & $-1.0(.3)$ \\
\hline \multicolumn{7}{|l|}{ Group Effect St. Dev. } \\
\hline State intercepts (st. dev.) & .3 & .3 & .3 & .0 & .3 & .2 \\
\hline State opinion slopes (st. dev.) & .2 & .3 & .2 & .3 & .3 & .4 \\
\hline Policy intercepts (st. dev.) & 1.9 & 1.5 & 1.5 & 1.5 & 1.3 & 1.4 \\
\hline Policy opinion slopes (st. dev.) & 2.3 & 1.9 & 1.9 & 1.8 & 1.6 & 1.7 \\
\hline Deviance Information Criterion (DIC) & 2154 & 2103 & 2030 & 2081 & 2068 & 1978 \\
\hline
\end{tabular}

All are multilevel logistic regression (logit) models with varying intercepts and slopes for opinion by policy and by state. Continuous variables are standardized (subtracting the mean and dividing by two standard deviations, putting them on the same scale as each other and roughly the same scale as the dichotomous variables). $\mathrm{N}=1,950$, except for models with partisan legislature, which drop Nebraska's 39 observations. Directional predictions use one-tailed tests: ${ }^{*}<.10,{ }^{* *}<.05$. 
indirect effect on responsiveness, by making term limits more likely-but this is the only evidence we find for a citizen initiative effect. $^{7}$

This leaves political context. Turnout and one-party dominance have effectively zero effect on responsiveness and congruence, but the interest group environment matters a great deal. Having a powerful interest group on the same (opposite) side as the opinion majority increases (decreases) the chance of congruence by up to $18 \%$. A liberal (conservative) interest group increases (decreases) the likelihood of having the liberal policy, all else equal, by up to $14 \%$. To put this in context, one would have to increase policy support by about nine percentage points to make up for having a powerful interest group opposed to the policy; for congruence, the majority size would have to increase by nine points to make up for a powerful interest group opposed to the majority. (See the SI for a supplemental result showing the density/number of interest groups does not affect responsiveness or congruence significantly.)

\section{Explaining the Democratic Deficit}

We next expand on these regression results to account for both the magnitude and the ideological direction of the democratic deficit.

\section{Magnitude}

We can use our model of congruence to apportion the "blame" for the democratic deficit across the possible culprits. Recall that $48 \%$ of policies are congruent with opinion majorities; our model also predicts $48 \%$. If we decrease salience to the minimum across issue areas, or increase it to the maximum, congruence hits $26 \%$ and $56 \%$, respectively. Suppose that we maximized professionalization, making every state the equivalent of California in this regard. Our point prediction based on our final model is that congruence would then occur $62 \%$ of the time. Giving every state term limits would increase congruence to $57 \%$. Doing both would increase it to $71 \%$.

If we remove interest group effects, congruence would be a whopping 49\%. How can dropping interest groups have no effect? Powerful interest groups restrain opinion majorities from achieving congruence; they also enable

\footnotetext{
${ }^{7}$ These main institutional findings are robust to simple t-tests or to reducing our congruence model to an OLS model of a simple count index by state, ranging from 13 to 27 congruent policies (again, see the SI). Moving from New Hampshire to California (no term limits to having term limits; from least professionalization to most), the effect is roughly eight additional congruent policies-close to $60 \%$ of the range of the congruence index.
}

them when aligned in their favor. For the policies we study, aggregating across states and policies, we find no net effect. If we consider congruence at the state level (aggregating over policies within each state), however, the picture is more complicated. Some states do better, others worse. Without interest group effects, the average increase in congruence is about $4 \%$, and the average decrease is about $4 \%$. We find a similar canceling out for elite partisan effects and voter ideology effects.

In short, overall congruence (summed across all states) is most affected by professionalization, term limits, and salience, but not by ideology, partisanship, and interest group pressure, which only affect the degree of incongruence within each state (sometimes helping, sometimes hurting). Nor do interest groups or voter ideology affect net policy liberalism (summed across states). An average state has 19 liberal opinion majorities, and our main responsiveness model predicts it will have 16 liberal policies. Dropping out interest group effects or voter ideology effects leaves this nearly unchanged.

\section{Ideological Direction}

What about the type of incongruence? Some basic relationships are shown in Figure 1. The middle-right panel shows the percentage of incongruence that is liberal for each state against state voter ideology, and the bottomright panel shows liberal incongruence against the party control. The dashed regression line shows the southern states and the solid line the rest. Controlling for region, there is a clear, strong relationship between ideological incongruence and each predictor. A pooled regression line ignoring the southern intercept shift in the bottom-right panel would falsely suggest party control did not matter.

We can more fully model the percentage of incongruence that is in the liberal direction by state as follows (OLS regression): Liberal Incongruence $=47.5(1.4)+$ 7.6(2.6) $\times$ Ideology - 10.4(3.2) $\times$ South $+6.4(2.9) \times$ Years Democratic vs. Republican Unified Control + 1.2(2.2) $\times$ Interest Group Balance (including a liberal opinion index here shows no effect). Even after controlling for partisan control, voter ideology, and interest groups, "South" is a strong and significant determinant of how much of the democratic deficit in the state is conservative policy (overall, southern states have almost exactly the same level of congruence). Interest groups have a small but significant impact. Ideology and party control have roughly similar impact. Five additional years of Democratic control correlates to $2 \%$ more incongruence in the liberal (rather than conservative) direction. Again, the direction of incongruence is separable from the incongruence. For example, years 
of unified control (or even uncompetitive one-party dominance) do not seem to lead to more congruence, yet unified partisan control does predict the form of incongruence.

Conditional on there being incongruence, ideological or partisan factors affect the direction of incongruence. And the result is polarized policy. The histograms in Figure 1 showed the wider spread of liberal policy counts relative to the spread of liberal opinion majorities. One way to measure polarization is the standard deviation of the liberal policy count relative to that of the liberal opinion majority count. The current policy count standard deviation is 7.0. Removing interest group effects only reduces this to 6.7. Removing voter ideology effects, on the other hand, would reduce the standard deviation of state policy counts to 3.8 , much closer to the 3.4 standard deviation in liberal opinion majority counts. Overresponsiveness to ideology is thus responsible for most of the polarization we observe.

\section{Conclusion}

What do our results tell us about the quality of democratic government at the state level? First, state governments are generally responsive to voter preferences across a wide range of issue areas, particularly when salience is high, even after controlling for the ideology of state voters and elected elites. Policy-specific opinion often has the largest substantive impact, indicating that it is indeed a key driver of policymaking.

We agree that "state political structures appear to do a good job in delivering more liberal policies to more liberal states and more conservative policies to more conservative states" (Erikson, Wright, and McIver, 1993, 95). Our findings, however, suggest a far deeper form of representation than simple ideological correspondence. It is not only that more liberal states have more liberal policies, but that states with voters who want a specific policy are more likely to get it.

That policy-specific opinion is such a strong predictor of policy seems reassuring as to the ability of state government to reflect constituent will. Indeed, it suggests that the states should earn a rather respectable grade for the responsiveness portion of the democratic performance test. However, we have also uncovered a clear "democratic deficit" — states effectively translate majority opinion into policy only about half the time, a clear "failing" grade on the congruence test. This is true even when majorities are large and when salience is high, which raises significant questions about the democratic performance of state government. ${ }^{8}$

For aggregate congruence, salience and (some) institutional effects are far more important than interest group or partisan effects. That said, these forces do tell us in which ideological direction policy will "err" within each state when it does not match opinion majorities. It is not that conservative states have only conservative opinion majorities, and thus only liberal incongruence. Rather, they instead have too many conservative policies relative to their number of conservative opinion majorities. The ideological direction of incongruence correlates to the standard red-state/blue-state map. In states where voters are ideologically conservative, policy, when incongruent with opinion majorities, tends to be more conservative than preferred by the median voter on that policy (that is, incongruence occurs in the form of liberal opinion majorities and conservative policy). In liberal states, the opposite is true. Thus, states tend to "overshoot" relative to the median voter's specific policy preferences. This leads to greater policy polarization than is warranted by such preferences, caused primarily by over-"responsiveness" to voter ideology. The bottom line is polarized (ideologically sorted) state policy slates, relative to less polarized (ideologically mixed) opinion majorities. ${ }^{9}$ Perhaps this is a consequence of a well-ordered two-party system, in which the parties form distinct blocs.

Clearly, responsiveness to voter ideology is still an important form of responsiveness, even if we might think responsiveness to policy-specific opinion preferable at least some of the time. State lawmakers might be doing the best they can to represent their constituents given insufficient information about preferences. Indeed, given the limits of specific responsiveness, overresponsiveness to ideology can sometimes be helpful, particularly when opinion majorities are in line with ideology. Of course, politicians could simply be satisfying their ideological base in spite of majority opinion. The median voter simply might not have sufficient intensity of opinion for some policies, so that politicians know they can shirk. Again, the

${ }^{8}$ One could, of course, prefer incongruence on normative grounds-e.g., women's rights groups would not be unhappy when majority opinion support for abortion restrictions goes unsatisfied, and nor would gay rights opponents be unhappy with unsatisfied majority support for employment nondiscrimination for gays and lesbians.

${ }^{9}$ Note that detecting this would be quite difficult without opinion and policy measured on the same scale (and without the MRP technology). It also suggests that some of the relationship between ideology and policy found in previous work might be overresponsiveness (as was cautioned by Erikson, Wright, and McIver 1993, 93). 
two-party system makes it more difficult to hold lawmakers accountable policy by policy. Finally, some policies may be easier to frame and defend to the public in symbolic or ideological terms, rather than policy-specific terms.

Institutional design can enhance responsiveness and congruence. We find that legislative professionalization has a strong, robust, and positive effect on both responsiveness and congruence. To the extent that professionalization leads to disadvantages such as insulation of legislators, this effect seems overridden by its responsiveness-enhancing effects. Interestingly, some have pushed to roll back professionalization to punish unpopular legislators and in response to perceived state government failure (e.g., a ballot measure in California called the "Citizen Legislature Act" to make its legislature part-time). Ironically, then, concerns about shortfalls in government performance may lead to greater shortfalls in government performance. Indeed, we find that the length of legislative sessions is the key component of professionalization (so that the California ballot measure would be particularly counterproductive). The only other institutional feature found to increase responsiveness and congruence is term limits. On the other hand, the citizen initiative (even at high levels of use) and an elected judiciary do not seem to do much for majoritarianism. The term limits effect may be an indirect effect of the citizen initiative, to the extent that term limits are almost never enacted in states without the initiative. ${ }^{10}$

The opinion-policy relationship is also affected by interest group balance, but our policy-specific interest group scores show that the effects are not black-andwhite. Interest groups can enable or block opinion majorities. Because of this and because the balance of interest groups is the key, interest groups have only a small impact on the net amount of incongruence and net number of liberal policies. They do have a disparate impact across states: whereas some states would have higher congruence without interest groups, other states would have lower congruence.

Finally, our analysis has important implications for our assessment of American federalism. Some argue that state governments, being closer to the people, are better able to tailor public policy to the preferences of their constituents than is the national government. Allowing states to set policy thus accommodates heterogeneous

\footnotetext{
${ }^{10}$ Of course, if institutional "effects" are simply spurious correlations, that would not change the fact that states are performing quite poorly in congruence. Future work could consider this further, examine temporal dynamics, and study congruence patterns in more detail.
}

preferences across jurisdictions and improves aggregate welfare. The strength of this claim, however, rests upon the heretofore untested assumption that state elected officials effectively match policy to local opinion. We show clear evidence to the contrary. While a strong relationship between state ideology and government policy is certainly suggestive of of good democratic performance as well as suggesting federalism is welfare improving, we show that even this strong relationship can mask potentially significant shortcomings in statehouse democracy. ${ }^{11}$

\section{References}

Arceneaux, Kevin. 2002. "Direct Democracy and the Link between Public Opinion and State Abortion Policy." State Politics and Policy Quarterly 2(4): 372-88.

Baumgartner, Frank R., and Bryan D. Jones. 1993. Agenda and Instability in American Politics. Chicago: University of Chicago Press.

Berkman, Michael B., and Eric Plutzer. 2005. Ten Thousand Democracies: Politics and Public Opinion in America's School Districts. Washington, DC: Georgetown University Press.

Berry, William D., Evan J. Ringquist, Richard C. Fording, and Russell L. Hanson. 1998. "Measuring Citizen and Government Ideology in the American States, 1960-93." American Journal of Political Science 42(1): 327-48.

Brace, Paul, Kellie Sims-Butler, Kevin Arceneaux, and Martin Johnson. 2002. "Public Opinion in the American States: New Perspectives Using National Survey Data.” American Journal of Political Science 46(1): 173-89.

Carey, John M., Richard G. Niemi, and Lynda W. Powell. 2000. Term Limits in State Legislatures. Ann Arbor: University of Michigan Press.

Druckman, James N., and Lawrence R. Jacobs. 2006. "Lumpers and Splitters: The Public Opinion Information That Politicians Collect and Use." Public Opinion Quarterly 70: 453-76.

Dye, Thomas R. 1966. Politics, Economics, and the Public: Political Outcomes in the American States. Chicago: Rand McNally.

Erikson, Robert S., Gerald C. Wright, and John P. McIver. 1993. Statehouse Democracy: Public Opinion and Policy in the American States. Cambridge: Cambridge University Press.

Gelman, Andrew, and Thomas C. Little. 1997. "Poststratification into Many Categories Using Hierarchical Logistic Regression.” Survey Methodology 23(2): 127-35.

Gerber, Elisabeth R. 1996. "Legislative Response to the Threat of the Popular Initiative." American Journal of Political Science 40: 99-128. ${ }^{11}$ Our ability to explore these shortcomings, differences between
congruence and responsiveness, and the ideological bias in policy-
making is a direct payoff of being able to put policy and opinion on
the same metric. Key to this are the MRP opinion estimation tech-
nique and the "crosshair technology" used to assess responsiveness. 
Gerber, Elisabeth R. 1999. The Populist Paradox: Interest Group Influence and the Promise of Direct Legislation. Princeton, NJ: Princeton University Press.

Haider-Markel, Donald P., and Matthew S. Kaufman. 2006. "Public Opinion and Policy Making in the Culture Wars: Is There a Connection Between Opinion and State Policy on Gay and Lesbian Issues?" In Public Opinion in State Politics, ed. Jeffrey E. Cohen. Stanford, CA: Stanford University Press, 163-82.

Haider Markel, Donald P., and Kenneth J. Meier. 1996. “The Politics of Gay and Lesbian Rights: Expanding the Scope of the Conflict." The Journal of Politics 58(2): 332-49.

Huber, G. A., and Sanford C. Gordon. 2004. "Accountability and Coercion: Is Justice Blind When It Runs for Office?" American Journal of Political Science 48(2): 247-63.

Kastellec, Jonathan P., Jeffrey R. Lax, and Justin H. Phillips. 2010. "Public Opinion and Senate Confirmation of Supreme Court Nominees." Journal of Politics 73(3): 767-84.

Kousser, Thad. 2005. Term Limits and the Dismantling of State Legislative Professionalism. Cambridge: Cambridge University Press.

Lascher, Edward L., Jr., Michael G. Hagen, and Steven A. Rochlin. 1996. "Gun Behind the Door: Ballot Initiatives, State Policies and Public Opinion." Journal of Politics 58(3): 760-75.

Lax, Jeffrey R., and Justin H. Phillips. 2009a. "How Should We Estimate Public Opinion in the States?" American Journal of Political Science 53(1): 107-21.

Lax, Jeffrey R., and Justin H. Phillips. 2009b. "Gay Rights in the States: Public Opinion and Policy Responsiveness." American Political Science Review 103(3): 367-86.

Lowery, David, and Virginia Gray. 1995. “The Population Ecology of Gucci Gulch, or the Natural Regulation of Interest Group Numbers in the American States." American Journal of Political Science 39(1): 1-29.

Lowery, David, and Virginia Gray. 2004. "A Neopluralist Perspective on Research on Organized Interests." Political Research Quarterly 57(1): 163-75.

Lupia, Arthur, Yanna Krupnikov, Adam Seth Levine, Spencer Piston, and Alexander Von Hagen-Jamar. 2010. "Why State Constitutions Differ in Their Treatment of Same-Sex Marriage." Journal of Politics 72(4): 122-235.

Maestas, Cherie. 2000. "Professional Legislatures and Ambitious Politicians: Policy Responsiveness of State Institutions." Legislative Studies Quarterly 25(4): 66390.

Matsusaka, John G. 2001. "Problems with a Methodology Used to Evaluate the Voter Initiative." Journal of Politics 63(4): $1250-56$

Matsusaka, John G. 2005. For the Many or the Few: The Initiative, Public Policy, and American Democracy. Chicago: University of Chicago Press.

Matsusaka, John G. 2010. "Popular Control of Public Policy: A Quantitative Approach.” Quarterly Journal of Political Science 5(2): 133-67.

Monogan, James, Virginia Gray, and David Lowery. 2009. "Public Opinion, Organized Interests, and Policy Congruence in Initiative and Noninitiative States." State Politics and Policy Quarterly 9(3): 304-24.
Mooney, Christopher Z., and Mei-Hsein Lee. 1995. "Legislating Morality in the American States." American Journal of Political Science 39(3): 599-627.

Norrander, Barbara. 2000. “The Multi-Layered Impact of Public Opinion on Capital Punishment Implementation in the American States." Political Research Quarterly 53: 771-94.

Norrander, Barbara. 2001. "Measuring State Public Opinion with the Senate National Election Study." State Politics and Policy Quarterly 1(1): 111-25.

Page, Benjamin I., and Robert Y. Shapiro. 1983. "The Effects of Public Opinion on Policy." American Political Science Review 77(1): 175-90.

Park, David K., Andrew Gelman, and Joseph Bafumi. 2006. "State-Level Opinions from National Surveys: Poststratification Using Multilevel Logistic Regression." In Public Opinion in State Politics, ed. Jeffrey E. Cohen. Stanford, CA: Stanford University Press, 209-28.

Phillips, Justin H. 2008. "Does Direct Democracy Weaken Party Government in the U.S. States?" State Politics and Policy Quarterly 8(2): 127-49.

Plotnick, Robert D., and Richard F. Winters. 1985. "A Political Economic Theory of Income Redistribution." American Political Science Review 79: 458-473.

Squire, Peverill. 2007. "Measuring State Legislative Professionalism: The Squire Index Revisited." State Politics and Policy Quarterly 7(2): 211-27.

Stimson, James A., Michael B. MacKuen, and Robert S. Erikson. 2002. The Macro Polity. Cambridge, MA: Cambridge University Press.

Thomas, Clive S., and Ronald J. Hrebenar. 2008. "Interest Groups in the States." In Politics in the American States: A Comparative Analysis. 9th ed., ed. Virginia Gray, Russell L. Hanson, and Herbert Jacob. Washington, DC: CQ Press.

Treadway, Jack M. 1985. Public Policymaking in the States. New York: Praeger.

Weber, Ronald E. 1999. “The Quality of State Legislative Representation: A Critical Assessment." Journal of Politics 61(3): 609-27.

\section{Supporting Information}

Additional Supporting Information may be found in the online version of this article:

- Robustness Checks and Extensions

- Table 1. Policies Included in Empirical Analysis, by Issue Area

- Table 2. Interest Groups and Policies

- Figure 3. Responsiveness and Congruence Models

- Figure 4. Predicted Probability of Congruence or Policy Adoption

Please note: Wiley-Blackwell is not responsible for the content or functionality of any supporting materials supplied by the authors. Any queries (other than missing material) should be directed to the corresponding author for the article. 


\section{The Democratic Deficit in the States Supporting Information (SI)}

Jeffrey R. Lax Justin H. Phillips

June 1, 2011 


\section{Online Appendix: Supporting Information (SI)}

\section{Robustness Checks and Extensions}

Basic robustness checks. In alternative specifications of our main models, we added mean liberal opinion across all 39 issues within each state (the coefficient on policy-specific opinion remained similar); let the slope of voter ideology vary by policy; and dropped potential outliers. Findings were the same. Our findings also remain the same if we weight the congruence model observations by the size of the majority, under the assumption that our congruence codings might be less accurate for smaller majorities. Shifting policies into other groups (e.g., stem cell research into Abortion or combining affirmative action with Immigration) did not change results other than yielding a smaller salience effect.

Salience. We also tried measuring salience as the percent of those who have an opinion, aggregated by policy or by policy area. The former produced nothing of interest; using just the latter was similar; controlling for the latter and continuing to include our newspaper measure of salience increased the size and statistical significance of the newspaper salience coefficient.

Institutions. We found no significant interaction effect between term limits and professionalization, results not shown. One could be concerned that term limits are endogenous, adopted as a remedy to unresponsive elected officials. This would possibly dampen or render negative the estimated effect of term limits and therefore would not explain the positive coefficient we find for the term limits-opinion interaction. While we include term limits as an institutional variable and also look at term limits as a policy, we reran models dropping 
it as a policy and results were unchanged. We tried to push our term limits finding further, evaluating whether the length of term limits (ranging from 6 to 12) mattered, but found no significant differences. It would make sense that lower salience policies would be the ones most affected by professionalization, but we cannot find such an effect with our data (an added interaction term was not significant and also not in the predicted direction).

Squire's index of professionalization has three components: staff per legislator, session length, and salary. Session length yields the best model fit among the three individually; yields the strongest effect when all are included; and then is the only component to reach statistical significance. We thus conclude that professionalization enhances responsiveness/congruence primarily by increasing available agenda space rather than through seat value (salary) or resources for investigating opinion (staff).

To explore the citizen initiative further, we replaced our indicator for having the citizen initiative with an indicator for High Use (using the initiative more than 50 times since adoption versus lower usage or not having it at all) and then with a measure of usage per year — we still found no positive effects. We also checked whether different levels of signature requirement for qualifying an initiative for the ballot (which range from $2 \%$ to $15 \%$ ) might condition direct democracy effects. Only in rather sparse models, and only at the minimum signature requirement $(2 \%)$, was the direct democracy effect significant and positive.

Our main institutional findings are robust to using simple t-tests. Term limit states have mean congruence of $53 \%$ against $47 \%$ without; states with above average professionalization have $51 \%$ congruence against $47 \%$ without (both differences are significant at 95\%). Contrast this with the citizen initiative: states with it have mean congruence of $50 \%$; without $47 \%(\mathrm{p}=.3)$. They are also robust to using an index model is Congruence Index 
$=17.2(.9)+2.2(.9) \times$ Professionalization $+2.3(1.3) \times$ Term Limits (standard errors in parentheses). In a simple model of the count of liberal policies, generally only the count of liberal opinion majorities in the state or average liberal policy support has a significant effect (not, for example, ideology, voter or elite). An additional liberal opinion majority (that is, for one more policy) actually corresponds to over one additional liberal policy, suggesting overresponsiveness. A two-standard deviation swing in average liberal policy support correlates to eight additional liberal policies, even controlling for state ideology (which has half that effect). A two-standard deviation swing in professionalization or having term limits makes an additional 2 policies congruent (about $16 \%$ of the range).

Interest Groups. It is not the case that opinion is simply a proxy for interest group activity. Moreover, our results are unchanged if we limit our sample to only those observations where there is no related powerful interest group, or to observations where there is no interest group on the liberal side, or to observations where there is no interest group on the conservative side. We also explored whether an interest group aligned with the majority had a different magnitude of effect than one opposed to it; they were not statistically different.

Research also shows that states vary widely with respect to the density of organized interests (Gray and Lowery 1995, 2001). While a great deal has been written about the potential consequences of this variation, analysis is fraught with theoretical and empirical difficulties. High interest group density may be good if it means that groups represent a broad array of policy needs and transmit these preferences to the government. Or it might be bad if it means capture or gridlock. Density alone also does not tell us much about the balance between competing groups. Moreover, the size of state interest group populations 
has been shown to be endogenous to state political institutions. Berkman (2001) finds this to be true for legislation professionalization and Boehmke $(2002,2008)$ for the citizen initiative. Additionally, the size of the interest group community is influenced by the policy problems present in the state and proposed solutions (Lowery and Gray 1995, 2004). Perhaps not surprisingly, when we added interest group density (the number of registered lobbyists by state) to our analysis, we found no effect.

Political Context. We next tried supplementing our models with other measures of political context. While some argue divided government leads to gridlock, we found no evidence that divided government (the share of time that control was split between Democrats and Republicans over 1995-2005) leads to less congruence (in fact, it was weakly correlated to higher congruence). We also assessed whether legislative turnover itself explained congruence (with or without term limits) and found no meaningful effect.

Culture. Some attribute differences in state politics to political culture. Elazar (1984) argues that culture and values, dating back to settlement patterns in the early twentieth century, shape the operation of state political systems. We assessed whether congruence or responsiveness were aligned with his tripartite typology of states: "traditionalist," "individualist," and "moralist." We found little difference. As another way of picking up cultural differences, we tried a proxy for a state's populist tendencies - the presidential vote share of William Jennings Bryan against William McKinley in 1896. A populist tradition could directly impact responsiveness or have shaped institutional development. A long shot to say the least, we do find that there is more congruence in states with a higher Bryan vote. While not huge, the effect is still roughly half that of term limits or professionalization, 
and statistical significance hovers around the 90\% confidence level (two-tailed). This effect does not exist for current-day Democratic vote share. These effects become perhaps less surprising given that there is a correlation between Bryan vote and term limits, albeit weak (but not professionalization). The Bryan "effect" does persist when this is controlled for but might capture other "populist" institutions. More generally, we cannot rule out that culture shapes institutions (professionalization, term limits, and the like) and so has that indirect effect on congruence. Cultural differences across state might manifest in opinion differences. Our responsiveness and congruence results would stand, but we cannot rule out that culture has such an impact.

"Reverse Causality?" As Erikson, Wright, and McIver note, "conceivably it is the policy tendency of the state that drives public preferences rather than the other way around" (1993, 88). In this context, perhaps public support for liberal policies rises after the exposure to the policy itself. While we acknowledge the general problems of assessing causality in responsiveness research, we offer four responses. First, Erikson, Wright, and McIver themselves find no such effect and show evidence instead of the "normal" direction of causality. Second, as they argue, there are strong theoretical reasons to suppose that opinion affects policy and the choices of policymakers - would we expect a New York legislator who was moved to the Alabama state house to continue to vote the way he did in New York? - but at best limited theoretical reasons to think that people simply adopt the preferences that match their states policy. Third, demographic characteristics, which are (relatively) fixed by state, explain a significant amount of the variation in support for liberal policies. We inspected the state random effects in the MRP survey response models - these are the intercept shifts for each 
individual state beyond the effects of demographics. For some policies, there is effectively zero residual state-level variation after we control for demographics and region. Therefore, it is highly unlikely that having a liberal policy is causing liberal. Even though small residual state variation exists for other policies, demographics still explain much variation in opinion, so policy adoption can still only have a relatively small effect on state estimates by affecting intercept shifts or national correlations. Moreover, if having the liberal policy caused higher opinion, then having the policy would be correlated with positive intercept shifts (higher state opinion after controlling for demographic and regional effects). There was no such systematic relationship. Finally, for five policies (same-sex marriage, civil unions, hate crimes, medical marijuana, and verify), we have sufficient polling data before policy adoption to generate estimates that cannot generally have been influenced by respondents exposure to the policy. The responsiveness correlations remain strong for all five.

\section{Notes}

Poll selection Our search was limited to polls conducted in the past decade that identified the state of residence for all respondents. The polls are random national samples conducted by Gallup, Pew, ABC News, CBS News, Harvard, AP, Kaiser, and Newsweek. We combine polls on each policy into a single internally-consistent dataset for that policy. There are, of course, slight variations across polls in question wording and ordering (each polling firm tends to use the same wording over time). We control for such differences using random effects.

Effect Magnitude Notes. In terms of partisanship, the states with congruence scores that would be higher were there no partisan effects include AL, OH, WV, LA, and MD. 
Those that would be lower include NJ, NY, CT, IL, DE, VT, and WA. Those states hurt most by interest group activity are AZ, DE, ME, OR, RI, WI, and WV. Those states helped the most are GA, NJ, UT, and VA. (If there is a pattern here, it escapes us.) Education and Gay Rights policies are held back in congruence (each would be $5 \%$ higher) by interest groups such as teacher's unions and social conservative groups respectively; Abortion policies would be slightly lower in congruence (3\%). At average state ideology, we would see slightly more congruence in Abortion policies but less in Gay Rights, Health, and Law Enforcement (differences of up to 4\%). Removing party effects would have a smaller net effect at this level of aggregation.

Regression notes. There is little residual state variation in responsiveness slopes, but there remains residual variation in slopes across policies. Coding policy as having the liberal policy, the mean is $44 \%$; we would, with the full model, predict $42 \%$ ( $80 \%$ correctly predicted, proportional reduction of error $55 \%$. Mean congruence is $48 \%$; we would, with the full model, predict $48 \%$ (79\% correctly predicted, proportional reduction of error $56 \%$.

\section{Supplemental Citations:}

Berkman, Michael. 2001. "Legislative Professionalism and the Demand for Groups: The Institutional Context and Interest Population Density." Legislative Studies Quarterly 26: 661-79.

Boehmke, Frederick J. 2002. "The Effect of Direct Democracy on the Size and Diversity of State Interest Group Populations." Journal of Politics 64:827-44.

Boehmke, Frederick J. 2008. "The Initiative Process and the Dynamics of State Interest Group Populations." State Politics and Policy Quarterly 8(4): 362-83. 


\begin{tabular}{|c|c|}
\hline Policy & Survey Question, Number of Survey Respondents, Policy Data Source Code, and Survey Years \\
\hline \multicolumn{2}{|l|}{ ABORTION } \\
\hline Counseling & $\begin{array}{l}\text { - Do you favor or oppose a law requiring doctors to inform patients about alternatives to abortion } \\
\text { before performing the procedure? } N=2004 \text {; Policy Data Source Code }=(\text { a); Years }=2003,2005\end{array}$ \\
\hline Parental Consent & $\begin{array}{l}\text { - Do you favor or oppose a law requiring teenagers to have their parents' permission? N=3010; (a); } \\
2003,2005\end{array}$ \\
\hline Parental Notification & $\begin{array}{l}\text { - Do you favor or oppose a law requiring that parents of teenagers must be notified? } \mathrm{N}=1002 \text {; (a); } \\
2005\end{array}$ \\
\hline Partial Birth Abortion & $\begin{array}{l}\text { - Now I would like to ask your opinion about a specific abortion procedure known as a "late term" } \\
\text { abortion or "partial birth" abortion, which is sometimes performed on women during the last few } \\
\text { months of pregnancy. Do you think that the government should make this procedure illegal, or do } \\
\text { you think that the procedure should be legal? N=4582; (a);2000, 2003, 2007 }\end{array}$ \\
\hline Waiting Period & $\begin{array}{l}\text { - Do you favor or oppose a law requiring women seeking abortions wait } 24 \text { hours before having the } \\
\text { procedure done? } \mathrm{N}=2004 ; \text { (a); } 2003,2005\end{array}$ \\
\hline \multicolumn{2}{|r|}{ 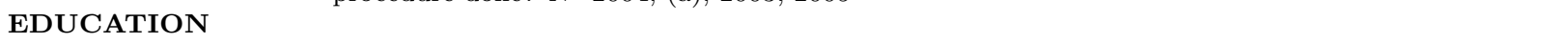 } \\
\hline Affirmative Action & $\begin{array}{l}\text { - Do you approve or disapprove of affirmative action admissions programs at colleges and law schools } \\
\text { that give racial preferences to minority applicants? } \mathrm{N}=5831 ;(\mathrm{b}) ; 2003\end{array}$ \\
\hline Charter Schools & $\begin{array}{l}\text { - Charter schools operate under a charter or contract that frees them from many of the state } \\
\text { regulations imposed on public schools and permits them to operate independently. Do you favor or } \\
\text { oppose the idea of charter schools? } \mathrm{N}=7778 ;(\mathrm{c}) ; 1999,2000,2003\end{array}$ \\
\hline Testing & $\begin{array}{l}\text { - Do you favor or oppose using a single standardized test in the public schools in your community } \\
\text { to determine whether a student should receive a high school diploma? } \mathrm{N}=4843 \text {; (d); 1999, } 2003\end{array}$ \\
\hline Vouchers & $\begin{array}{l}\text { - Please tell me if you agree or disagree with the following statement. Parents should get tax-funded } \\
\text { vouchers they can use to help pay for tuition for their children to attend private or religious schools } \\
\text { instead of public schools? } \mathrm{N}=11574 ;(\mathrm{e}) ; 2001,2002 ; 2003\end{array}$ \\
\hline \multicolumn{2}{|c|}{ ELECTORAL REFORM } \\
\hline \multirow{2}{*}{$\begin{array}{l}\text { Corporate \& Union } \\
\text { Contributions }\end{array}$} & ibu- \\
\hline & $200 ;(\mathrm{e})$ \\
\hline $\begin{array}{l}\text { Individual Contribu- } \\
\text { tions }\end{array}$ & $\begin{array}{l}\text {-Which one of the following two positions on campaign financing do you favor more: } 1 \text {. Limiting } \\
\text { the amount of money individuals can contribute to political campaigns, OR 2. Allowing individuals } \\
\text { to contribute as much money to political campaigns as they'd like? N=1676; (e); 1999; } 2000\end{array}$ \\
\hline Photo ID & $\begin{array}{l}\text { - On Election Day, should voters be required to show an official photo identification, such as a } \\
\text { Driver's License, or shouldn't they have to do this? } \mathrm{N}=2006 ;(\mathrm{e}) ; 2006\end{array}$ \\
\hline Recall Elections & $\begin{array}{l}\text { - Do you think it is a good idea to have a law in your state that allows voters to recall an elected } \\
\text { official before his or her term in office is up? } \mathrm{N}=2010 ;(\mathrm{e}) ; 2003\end{array}$ \\
\hline Term Limits & $\begin{array}{l}\text { - Voters in a number of states have enacted term limits... Whom do you agree with more-those who } \\
\text { think term limits is a good idea, or those who think it is a bad idea? } \mathrm{N}=1007 ;(\mathrm{e}) ; 2003\end{array}$ \\
\hline \multicolumn{2}{|l|}{ GAMING } \\
\hline Casinos & $\begin{array}{l}\text { - Please tell me whether you would approve or disapprove of legalizing each of the following types } \\
\text { of betting in YOUR state to help raise revenues...Casino gambling } \mathrm{N}=3260 ;(\mathrm{d}) ; 2006\end{array}$ \\
\hline Lotteries & $\begin{array}{l}\text { - Please tell me whether you would approve or disapprove of legalizing each of the following types } \\
\text { of betting in YOUR state to help raise revenues...Lotteries for cash prizes } \mathrm{N}=4264 ;(\mathrm{d}) ; 1996,2006\end{array}$ \\
\hline \multicolumn{2}{|l|}{ GAY RIGHTS } \\
\hline Adoption & $\begin{array}{l}\text { - Do you favor adoption rights for gay and lesbian couples so they can legally adopt children? } \\
\mathrm{N}=10208 ; \text { (f); } 1994,1996-98,2000,2004,2006-07\end{array}$ \\
\hline Civil Unions & $\begin{array}{l}\text { - Would you favor or oppose a law that would allow homosexual couples to legally form civil unions, } \\
\text { giving them some of the legal rights of married couples, or do you not have an opinion either way? } \\
\mathrm{N}=12187 \text {; (f); } 2000,2002-04 ; 2007\end{array}$ \\
\hline $\begin{array}{l}\text { Employment Protec- } \\
\text { tions }\end{array}$ & - Do you favor or oppose laws to protect gays against job discrimination? $\mathrm{N}=6305 ;$ (f); 2000, 2004-05 \\
\hline Hate Crimes & $\begin{array}{l}\text { - If a hate crime law were enacted in your state, do you think that homosexuals should be covered? } \\
\mathrm{N}=2022 ; \text { (f); } 1999-00\end{array}$ \\
\hline Health Benefits & $\begin{array}{l}\text { - Should there be health insurance and other employee benefits for gay spouses? } \mathrm{N}=5654 \text {; (f); } \\
1997-98,2000,2004\end{array}$ \\
\hline Housing Protections & $\begin{array}{l}\text { - Do you support laws to protect gays and lesbians form prejudice and discrimination in housing? } \\
\mathrm{N}=6783 ; \text { (f); } 1994,1996-98,2000,2004\end{array}$ \\
\hline Marriage & $\begin{array}{l}\text { - Do you think there should or should not be legally-sanctioned gay and lesbian marriages? } \mathrm{N}=39483 \\
\text { (f); } 1994,1996-00,2003-08\end{array}$ \\
\hline Sodomy & $\begin{array}{l}\text { - Do you think homosexual relations between consenting adults should or shouldn't be equal? } \\
\mathrm{N}=12578 ;(\mathrm{g}) ; 1994,1996,1999,2003-05\end{array}$ \\
\hline
\end{tabular}

Table 1: Policies Included in Empirical Analysis, by Issue Area. Survey question wording and policy data source are shown, along with the years of the surveys (policy data is as of 2008). 


\begin{tabular}{|c|c|}
\hline Policy & Survey Question, Number of Survey Respondents, Policy Data Source Code, and Survey Years \\
\hline \multicolumn{2}{|l|}{ HEALTH CARE } \\
\hline Assisted Suicide & $\begin{array}{l}\text { - If someone is terminally ill, is in great pain and wants to kill themselves, should it be legal for a } \\
\text { doctor to help them to commit suicide or not? } \mathrm{N}=5536 ;(\mathrm{h}) ; 2005,2006\end{array}$ \\
\hline Medicaid Access & $\begin{array}{l}\text { - I am going to read you a list of some ways that have been suggested to deal with the financial } \\
\text { problems of Medicaid. Please tell me if you would favor or oppose such a proposal...Reducing the } \\
\text { number of people who qualify for Medicaid N=1201; (a); } 2005\end{array}$ \\
\hline Medical Marijuana & $\begin{array}{l}\text { - Do you think adults should be allowed to legally use marijuana for medical purposes if their } \\
\text { doctor prescribes it or do you think that marijuana should remain illegal even for medical purposes? } \\
\mathrm{N}=3287 \text {; (d); } 1997,2002,2003\end{array}$ \\
\hline SCHIP Coverage & $\begin{array}{l}- \text { Do you think children in a family of four making about } \$ 60,000 \text { per year should be eligible for the } \\
\text { SCHIP program, or not } \mathrm{N}=1527 ; \text { (a); } 2007\end{array}$ \\
\hline Stem Cell & - Do you support or oppose embryonic stem cell research? N=5090; (e); 2004-06 \\
\hline \multicolumn{2}{|l|}{ IMMIGRATION } \\
\hline Bilingual education & $\begin{array}{l}\text { - Do you think all public school classes should be taught in English or do you think children of } \\
\text { immigrants should be able to take some courses in their native language? } \mathrm{N}=7706 ; \text { (i); 1999, } 2003\end{array}$ \\
\hline Drivers' Licenses & $\begin{array}{l}\bullet \text { Do you think state governments should or should not issue drivers' licenses to illegal immigrants? } \\
\mathrm{N}=2599 ; \text { (d); } 2007\end{array}$ \\
\hline Tuition & $\begin{array}{l}\text { - Do you think the children of illegal immigrants who graduate from high school in the U.S. should } \\
\text { be allowed to attend state public colleges at the same reduced in-state tuition rates as other state } \\
\text { residents, or should they pay higher tuition? } \mathrm{N}=2265 ; \text { (d);2007 }\end{array}$ \\
\hline $\begin{array}{l}\text { Verification of Citizen- } \\
\text { ship }\end{array}$ & $\begin{array}{l}\text { - Would you favor or oppose creating a new government database of everyone eligible to work both } \\
\text { American citizens and legal immigrants, and requiring employers to check that database before hiring } \\
\text { someone for ANY kind of work? } \mathrm{N}=6003 ; \text { (d); } 2006\end{array}$ \\
\hline \multicolumn{2}{|c|}{ LAW ENFORCEMENT } \\
\hline Assault weapons ban & $\begin{array}{l}\text { - First, would you vote for or against a law which would make it illegal to manufacture, sell, or } \\
\text { possess semi-automatic guns known as assault rifles? } \mathrm{N}=1004 ;(\mathrm{j}) ; 2000\end{array}$ \\
\hline Concealed weapons & $\begin{array}{l}\text { - Do you favor or oppose preventing gun owners from carrying a concealed gun in public? } \mathrm{N}=2593 \text {; } \\
\text { (j); } 2001,2008\end{array}$ \\
\hline Death Penalty & - Are you in favor of the death penalty for a person convicted of murder? N=12075; (k); 2005-07 \\
\hline Drug Crimes & $\begin{array}{l}\text { - Please tell me if you think mandatory prison sentences are a good idea for Non-violent drug crimes, } \\
\text { like possession or sale of illegal drugs. } \mathrm{N}=1502 ;(\mathrm{l}, \mathrm{m}, \mathrm{n}) ; 2006\end{array}$ \\
\hline Marijuana & $\begin{array}{l}\text { - What about in small amounts, for example three ounces or less? Do you favor or oppose the } \\
\text { legalization of marijuana in small amounts? } \mathrm{N}=2011 ;(\mathrm{o}) ; 2002-03\end{array}$ \\
\hline Waiting Period & $\begin{array}{l}\text { - Thinking about specific ways that the government has dealt with guns in the past, do you favor } \\
\text { or oppose each of the following: Requiring people who purchase a gun to wait a certain number of } \\
\text { days before they receive that gun? } \mathrm{N}=2593 ;(\mathrm{j}) ; 2001 ; 2008\end{array}$ \\
\hline \multicolumn{2}{|c|}{ POLICY DATA SOURCE CODES } \\
\hline (a) & Henry J. Kaiser Family Foundation \\
\hline (b) & Education Commission of the States \\
\hline (c) & USCharterSchools.org \\
\hline (d) & Stateline.org \\
\hline (e) & National Conference of State Legislators \\
\hline (f) & Human Rights Campaign \\
\hline$(\mathrm{g})$ & National Gay and Lesbian Task Force \\
\hline (h) & Euthanasia.com \\
\hline (i) & ProEnglish.org \\
\hline (j) & National Rifle Association \\
\hline$(\mathrm{k})$ & Death Penalty Information Center \\
\hline (l) & Justice Policy Institute \\
\hline (m) & Families Against Mandatory Minimums \\
\hline (n) & The Sentencing Project \\
\hline (o) & Working to Reform Marijuana Laws \\
\hline
\end{tabular}




\begin{tabular}{|c|c|c|}
\hline Policy & Liberal Interest Group & Conservative Interest Group \\
\hline \multicolumn{3}{|l|}{ ABORTION } \\
\hline Counseling & Pro-choice groups & Social conservative groups \\
\hline Parental consent & Pro-choice groups & Social conservative groups \\
\hline Parental notification & Pro-choice groups & Social conservative groups \\
\hline Partial birth abortion & Pro-choice groups & Social conservative groups \\
\hline Waiting period & Pro-choice groups & Social conservative groups \\
\hline \multicolumn{3}{|l|}{ EDUCATION } \\
\hline \multicolumn{3}{|l|}{ Affirmative action } \\
\hline Charter schools & Teachers unions & \\
\hline Testing & Teachers unions & \\
\hline Vouchers & Teachers unions & Social conservative groups \\
\hline \multicolumn{3}{|c|}{ ELECTORAL REFORM } \\
\hline \multicolumn{3}{|c|}{ Corporate \& union contributions } \\
\hline \multicolumn{3}{|c|}{ Individual contributions } \\
\hline \multicolumn{3}{|l|}{ Photo ID } \\
\hline \multicolumn{3}{|l|}{ Recall elections } \\
\hline \multicolumn{3}{|l|}{ Term limits } \\
\hline \multicolumn{3}{|l|}{ GAMING } \\
\hline Casinos & Gaming industry & Social conservative groups \\
\hline Lottery & Gaming industry & Social conservative groups \\
\hline \multicolumn{3}{|l|}{ GAY RIGHTS } \\
\hline Adoption & Gay rights groups & Social conservative groups \\
\hline Civil unions & Gay rights groups & Social conservative groups \\
\hline Employment protections & Gay rights groups & Social conservative groups \\
\hline Hate crimes & Gay rights groups & Social conservative groups \\
\hline Health benefits & Gay rights groups & Social conservative groups \\
\hline Housing protections & Gay rights groups & Social conservative groups \\
\hline Marriage & Gay rights groups & Social conservative groups \\
\hline Sodomy & Gay rights groups & Social conservative groups \\
\hline \multicolumn{3}{|l|}{ HEALTH CARE } \\
\hline Assisted suicide & & Social conservative groups \\
\hline \multicolumn{3}{|l|}{ Medicaid access } \\
\hline Medical marijuana & & Law enforcement \\
\hline \multicolumn{3}{|l|}{ SCHIP coverage } \\
\hline Stem cell & Pharmaceutical industry & Social conservative groups \\
\hline \multicolumn{3}{|l|}{ IMMIGRATION } \\
\hline Bilingual education & Teachers unions & \\
\hline \multicolumn{3}{|l|}{ Drivers' licenses } \\
\hline \multicolumn{3}{|l|}{$\begin{array}{l}\text { Tuition } \\
\text { Thens }\end{array}$} \\
\hline \multicolumn{3}{|l|}{ Verification of citizenship } \\
\hline \multicolumn{3}{|c|}{ LAW ENFORCEMENT } \\
\hline Assault weapons ban & Law enforcement & Gun rights groups \\
\hline Concealed weapons & Law enforcement & Gun rights groups \\
\hline Death penalty & & Law enforcement \\
\hline Drug crimes & & Law enforcement \\
\hline Marijuana & & Law enforcement \\
\hline Waiting period & Law enforcement & Gun rights groups \\
\hline
\end{tabular}

Table 2: Interest Groups and Policies. The table lists those groups that would tend to favor or oppose the liberal position on a policy; if a state had a powerful interest group of that type, the state was coded as having such an interest group for that policy. 

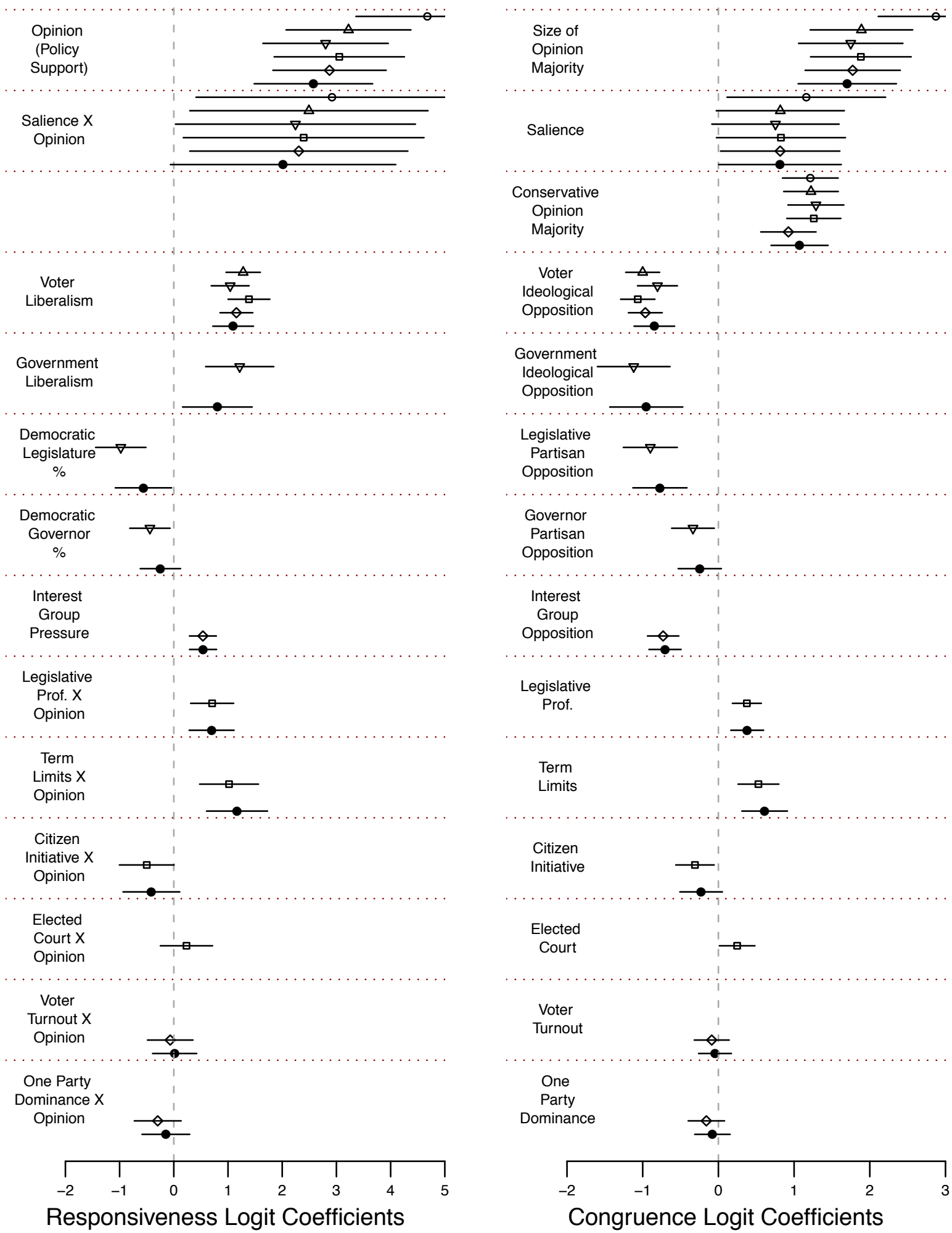

Figure 3: Responsiveness and Congruence Models We plot coefficients from six model variants. All are multilevel logistic regressions including varying intercepts and slopes by state and by policy. Confidence intervals are shown for the $90 \%$ level for two-tailed tests (equivalently, $95 \%$ for one-tailed). Starting from the most basic at the top, the o models include only opinion and salience (DIC model fit for responsiveness is 1969; for congruence, 2154). The $\triangle$ models add voter ideology (so far, these all remain in subsequent models) (DIC 1935; DIC 2103). The $\nabla$ add government ideology and partisanship measures (DIC 1878; DIC 2030). The $\square$ models remove these and add institutional variables (DIC 1912; DIC 2081). The $\diamond$ models remove these and political context variables (DIC 1916; DIC 2068). Our complete models(•) include all the variables except for Elected Court (DIC 1842; DIC 1976). 
Policy Adoption given Opinion

(by Salience Level)

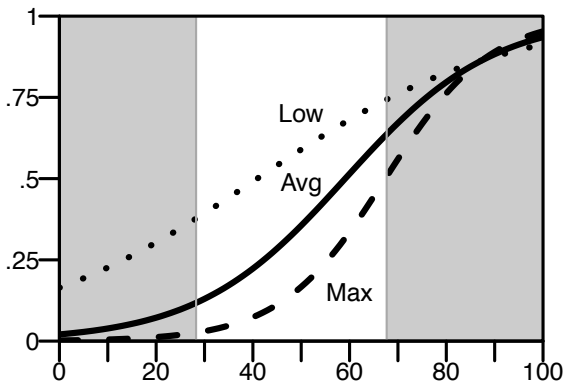

Policy Adoption given Opinion (Max vs. Min Professionalization)

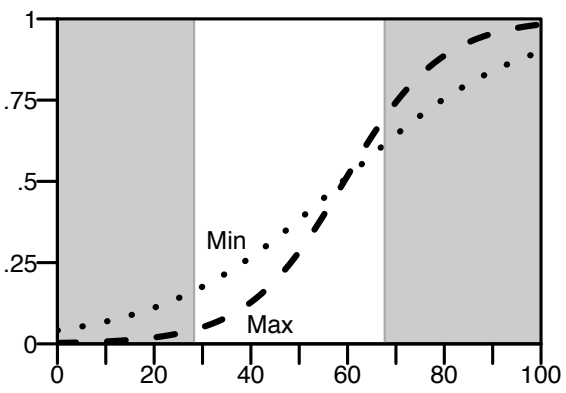

Policy Adoption given Opinion (Term Limits?)

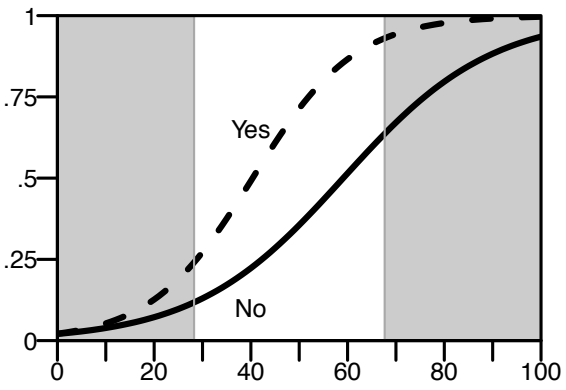

Policy Adoption given Opinion (Interest Group Pressure For/Against)

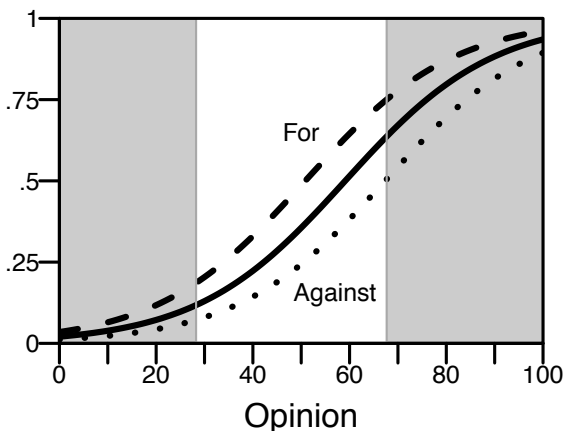

Congruence given Size of Majority

(by Salience Level)

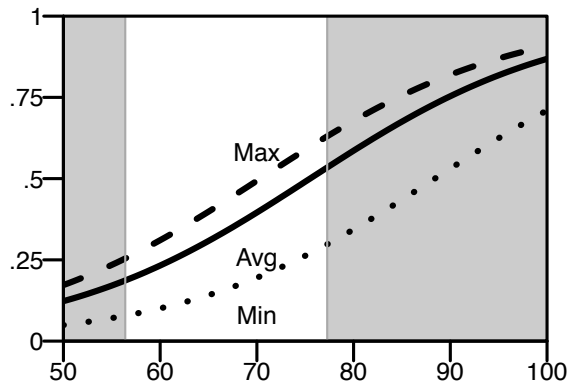

Congruence given Size of Majority (Min vs. Max Professionalization)

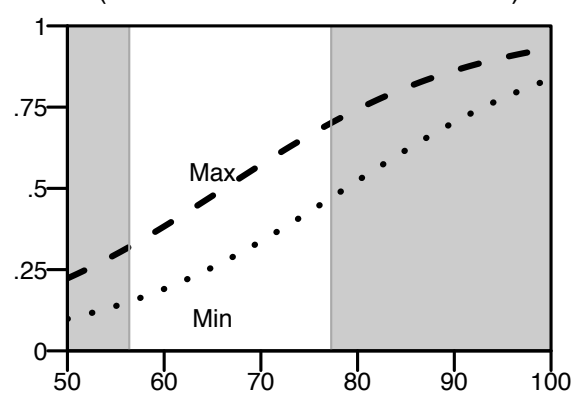

Congruence given Size of Majority (Term Limits?)

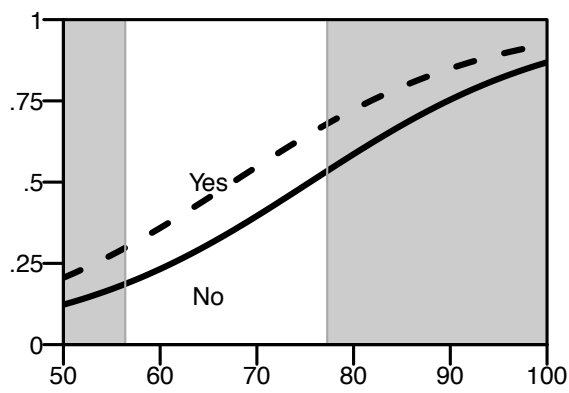

Congruence given Size of Majority (Interest Group Pressure For/Against)

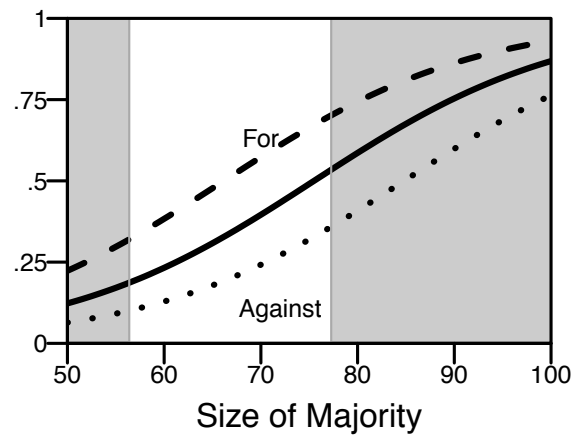

Figure 4: Predicted Probability of Congruence or Policy Adoption. Each graph plots the predicted probability of policy adoption or congruence derived from the final models in Figure ??. The default value of each continuous variable is its mean. Each dichotomous variable is set to zero. The non-shaded regions depict the range of opinion between low opinion and high opinion - that is, the two standard deviation region in which most observations fall. 